\title{
Article \\ Profiling of Human Neural Crest Chemoattractant Activity as a Replacement of Fetal Bovine Serum for In Vitro Chemotaxis Assays
}

\author{
Xenia Dolde ${ }^{1}$, Christiaan Karreman ${ }^{1}$, Marianne Wiechers ${ }^{1}$, Stefan Schildknecht ${ }^{2}$ and Marcel Leist ${ }^{1, *}$ (i) \\ 1 Department of Biology, University of Konstanz, 78457 Konstanz, Germany; \\ xenia.dolde@uni-konstanz.de (X.D.); christiaan.karreman@uni-konstanz.de (C.K.); \\ marianne.wiechers@uni-konstanz.de (M.W.) \\ 2 Department of Life Sciences, Albstadt-Sigmaringen University of Applied Sciences, \\ 72488 Sigmaringen, Germany; Stefan.Schildknecht@uni-konstanz.de \\ * Correspondence: marcel.leist@uni-konstanz.de; Tel.: +49-(0)7531-88-5037; Fax: +49-(0)7531-88-5039
}

Citation: Dolde, X.; Karreman, C.; Wiechers, M.; Schildknecht, S.; Leist, M. Profiling of Human Neural Crest Chemoattractant Activity as a Replacement of Fetal Bovine Serum for In Vitro Chemotaxis Assays. Int. J. Mol. Sci. 2021, 22, 10079. https:/ / doi.org/10.3390/ijms221810079

Academic Editor: James N. Sleigh

Received: 23 July 2021

Accepted: 14 September 2021

Published: 18 September 2021

Publisher's Note: MDPI stays neutral with regard to jurisdictional claims in published maps and institutional affiliations.

Copyright: (c) 2021 by the authors. Licensee MDPI, Basel, Switzerland. This article is an open access article distributed under the terms and conditions of the Creative Commons Attribution (CC BY) license (https:/ / creativecommons.org/licenses/by/ $4.0 /)$.

\begin{abstract}
Fetal bovine serum (FBS) is the only known stimulus for the migration of human neural crest cells (NCCs). Non-animal chemoattractants are desirable for the optimization of chemotaxis assays to be incorporated in a test battery for reproductive and developmental toxicity. We con-firmed here in an optimized transwell assay that FBS triggers directed migration along a con-centration gradient. The responsible factor was found to be a protein in the 30-100 kDa size range. In a targeted approach, we tested a large panel of serum constituents known to be chem-otactic for NCCs in animal models (e.g., VEGF, PDGF, FGF, SDF-1/CXCL12, ephrins, endothelin, Wnt, BMPs). None of the corresponding human proteins showed any effect in our chemotaxis assays based on human NCCs. We then examined, whether human cells would produce any fac-tor able to trigger NCC migration in a broad screening approach. We found that HepG2 hepa-toma cells produced chemotaxis-triggering activity (CTA). Using chromatographic methods and by employing the NCC chemotaxis test as bioassay, the responsible protein was enriched by up to 5000-fold. We also explored human serum and platelets as a direct source, independent of any cell culture manipulations. A CTA was enriched from platelet lysates several thousand-fold. Its temperature and protease sensitivity suggested also a protein component. The capacity of this factor to trigger chemotaxis was confirmed by single-cell video-tracking analysis of migrating NCCs. The human CTA characterized here may be employed in the future for the setup of assays testing for the disturbance of directed NCC migration by toxicants.
\end{abstract}

Keywords: neural crest cells; cell migration; chemotaxis; fetal bovine serum; human platelet lysate

\section{Introduction}

The directed migration of neural crest cells (NCCs) over large distances is essential for normal vertebrate development. Genetic defects interfering with this process can lead to a broad panel of malformations and disease syndromes, such as Hirschsprung's disease, Treacher Collins syndrome or Waardenburg syndrome [1,2]. Chemicals that interfere with NCC migration often lead to craniofacial defects in the developing fetus [3]. This is well documented for ethanol or pesticides, such as triadimefon [4]. Disturbed retinoic acid (RA) levels are an important cause of impaired NCC migration and differentiation. Under such conditions, craniofacial defects are observed in both animals and humans [5].

NCCs are multipotent cells generated at the lateral edges of the neural plate. During early fetal development, NCCs migrate long distances to their target sites, such as the skin, the skull and the intestine. They differentiate into a large variety of cell types, including neurons, melanocytes and chondrocytes [6]. NCCs are grouped into subpopulations according to their position within the anteroposterior axis of the embryo. Cranial NCCs build mainly structures of the head [7], cardiac NCCs contribute to the smooth muscle of the 
great vessel/aorta [8], and trunk NCCs give rise to sensory neurons, the sympathoadrenal system and pigment cells $[9,10]$.

Cell migration is a complex process involving several biological functions, e.g., adhesion of cells to the extracellular matrix (ECM), detachment from the substrate and remodeling of the cytoskeleton. During the migration process, protrusions are extended at the leading edge, whereas the trailing edge is contracted and cell material is moved to the front pole of the cell $[11,12]$. The process by which factors promote increased cell motility is called chemokinesis, whereas chemotaxis is defined as the guided movement of cells along a gradient of bound molecules, soluble factors or mechanical stimuli [13]. To perform chemotaxis, cells need to have increased motility but also display properties such as directional sensing and maintenance of polarity [14]. Polarized cells are defined by a front that has localized actin polymerization and a rear that is able to contract [14]. Directional sensing is the property of cells to compare receptor occupancy over their surface and to determine where the concentration is the highest [14]. In the presence of a chemoattractant gradient, the cells sense the gradient, align their polarity with it and finally migrate along the gradient [15].

The migration of NCCs is initiated by a process called epithelial-to-mesenchymal transition (EMT), which goes along with several motility-increasing changes that affect cell polarity and adhesive properties [16]. Chemotaxis has been observed for individual NCCs but also for groups of cells moving in a coordinated manner, e.g., wild geese [17]. Collective migration allows a cluster of NCCs to migrate faster and to follow a weak chemoattractant gradient, to which a single cell would be insensitive $[18,19]$. A cluster of migrating cells is defined by leader and follower cells, which differ in their gene expression [17]. The transcriptome patterns controlling such behavior are dependent on the local environment and experimental systems [20], and it is likely that chemotactically active NCCs differ from cells not following a gradient.

Various factors have been proposed so far as NCC chemoattractants, e.g., vascular endothelium growth factor (VEGF) for chicken cranial NCCs [21] and platelet-derived growth factor (PDGF) in cranial NCCs of the zebrafish [22], fibroblast growth factors (FGF) in the cranial, cardiac and trunk regions of mice [23], and stromal cell-derived factor 1 (SDF-1/CXCL12) in the cranial and trunk regions of chicken [24]. Current knowledge on NCC development has mainly been obtained from animal models. The most common in vivo or in vitro experiments to investigate NCC migration and chemotaxis were performed using Xenopus laevis, mouse, rat and chick NCCs $[21,23,25,26]$. Thus, most of the above-mentioned chemoattractants have not been confirmed to be such for human NCCs. Using human NCCs differentiated from human pluripotent stem cells (hPSCs) is slowly becoming attractive in the field, and several differentiation protocols are available [27-31]. These in vitro differentiation protocols gave new insights into the molecular mechanisms of human NCC development. The use of induced pluripotent stem cells (iPSCs) from patients has enabled disease modeling of neurocristopathies [32-35]. Moreover, experimental models based on human NCCs have helped to identify chemicals that inhibit migration $[30,36]$. Unfortunately, data on consistent, concentration-dependent chemotaxis stimuli are still lacking. Such a stimulus would be required to test whether chemicals can specifically impair directed migration.

At the moment, there are thousands of untested chemicals used in commerce, and an assessment of all their potentially harmful properties in complex animal models is not feasible. Due to potential species differences, human cell-based high-throughput screening (HTS) methods are required [37-39]. Such new approach methods (NAMs) should allow for the cheap and fast testing of many chemicals [40-44]. An NCC chemotaxis assay could be incorporated in a NAM test battery [45] and used in the context of next-generation risk assessment (NGRA) [46,47]. Based on this, animal-free risk assessment for the safety of compounds may be performed [48].

Indeed, several in vitro assays to investigate NCC migration have been established during the past ten years based on human NCCs differentiated from hPSCs $[30,49]$. In the 
original wound healing assay, a scratch was introduced in an NCC monolayer to create a cell-free area. Many toxicants interfering with the movement of cells into the gap have been identified. The more recently developed circular migration inhibition of neural crest cell (cMINC) assay is an improved version (robustness and throughput) of the original assay. As in the original wound healing assay, the NCCs migrate in a random manner into the cell-free zone $[36,50]$. Known NCC toxicants were confirmed (including valproic acid (VPA), methylmercury chloride, $\mathrm{As}_{2} \mathrm{O}_{3}, \mathrm{CdCl}_{2}$ and polychlorinated biphenyls (PCBs)), and several previously considered safe chemicals were proved to be hazardous $[30,45,50-52]$.

The above-mentioned assays model NCC migration, but they are not able to assess directed cell migration. Chemotaxis assays require a stable gradient of a chemoattractant, which can be sensed by the cells [13]. To construct such a gradient, there is an urgent need for a human NCC chemoattractant. To our knowledge, bovine serum is the only known stimulus of motility described in the literature. Based on its animal origin and its poorly standardized composition, it is not the ideal basis for an assay setup.

The aim of this study was therefore to identify better-defined chemoattractants to study directed NCC migration. The study set out to verify that FBS indeed triggers chemotaxis and not just chemokinesis. Then, various approaches were used to demonstrate that a protein factor is responsible for the chemotactic activity of FBS. Based on this knowledge, human cell lines were screened for their capacity to secrete such a factor, and HepG2 cells were found as suitable source. As an alternative and pure human starting material, platelet lysates were considered. They were found to contain a potent NCC chemoattractant, which was highly enriched in the course of this study.

\section{Results and Discussion}

\subsection{Establishment of a Chemotaxis Assay Based on Human NCCs}

FBS has been shown earlier to accelerate the mobility of NCCs [50], and it was therefore used here as a promising first candidate to establish a chemoattractant gradient for a chemotaxis assay. As the assay principle, we used a modified Boyden chamber approach $[53,54]$. Moreover, this setup has earlier been proven useful for studying inhibition of the movement of NCCs by test chemicals [36,52]. As cell source, we used NCCs differentiated from pluripotent stem cells. Such cells have been characterized by comprehensive transcriptome analysis, and they have been used successfully as test systems for in vitro assays $[36,45,49,55,56]$.

The main advantage of our assay is that cells (NCCs) are cultured on top of a porous membrane in the upper compartment of a two-chamber system and that migration of the cells through the membrane into the lower chamber can be easily quantified. For this reason, we termed our test: "neural crest-membrane translocation" (NC-MT) assay. In this system, a chemoattractant gradient can be established across the membrane by adding different concentrations of chemoattractant into the upper and lower chambers (Figure 1A). It was shown that the cells stay on the (lower surface of the) membrane once they have migrated. Therefore, quantification of migration was very straightforward: cells were stained and counted at the end of the migration period (6 h) (Figure 1B).

In order to verify that FBS triggers true chemotaxis, various experimental conditions were compared. Cells migrated only when a gradient across the membrane was established, and they sensed a higher FBS concentration in the lower compartment. Direct contact of cells to high concentrations of FBS in the upper compartment did not trigger migration across the membrane towards the lower compartment. We, therefore, conclude that the assay assesses genuine chemotaxis (Figure 1C). In this setup, many NCC chemoattractants, known from animal cell studies, were tested. None of them showed a chemotactic effect on human NCCs in the NC-MT assay (Figure 1D). Using the same assay, we found a chemotaxis-triggering activity (CTA) in human serum (huSerum), which was similar to the one in FBS. Thus, also human serum contains an NCC chemoattractant and can be used for assay setup (Figure 1D). 
A
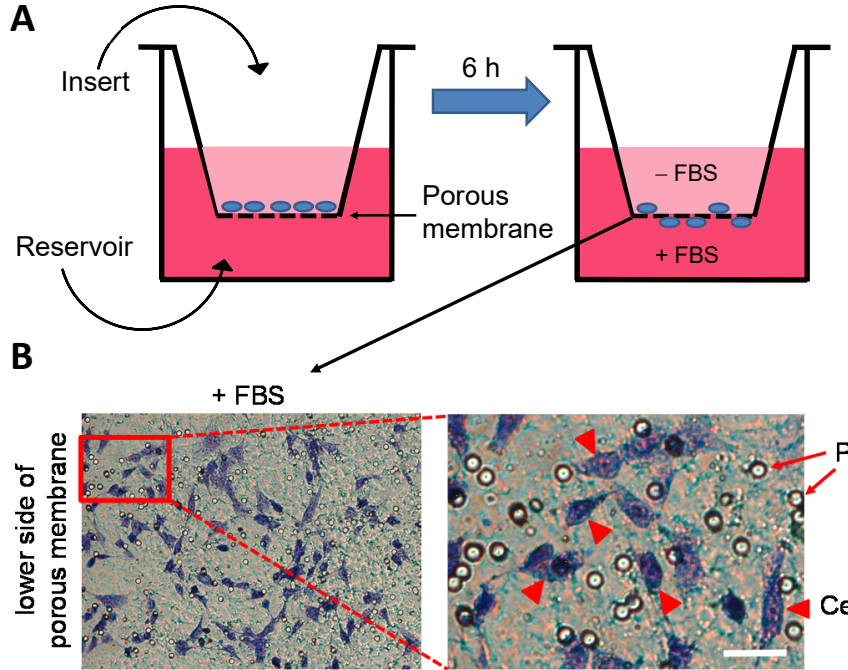

$\mathbf{E}$

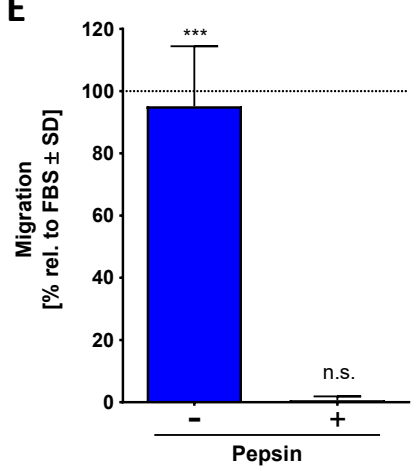

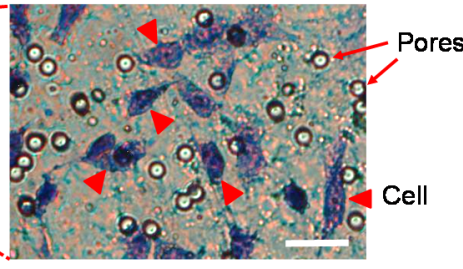

$\mathbf{F}$

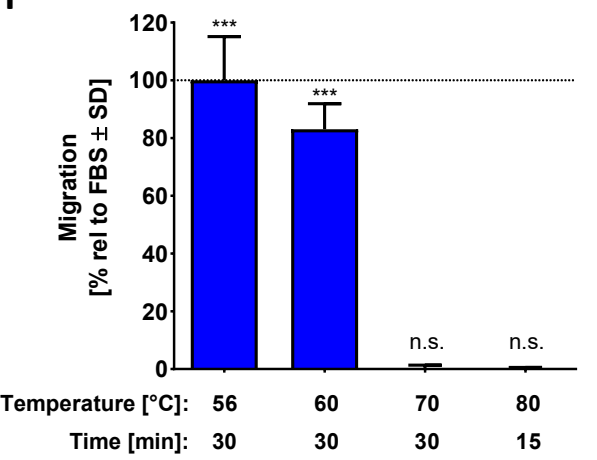

C

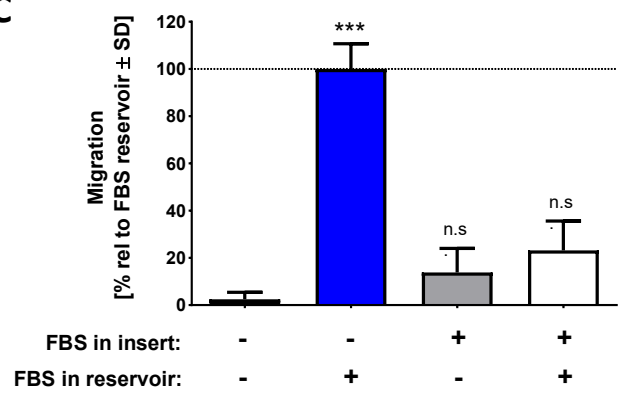

D

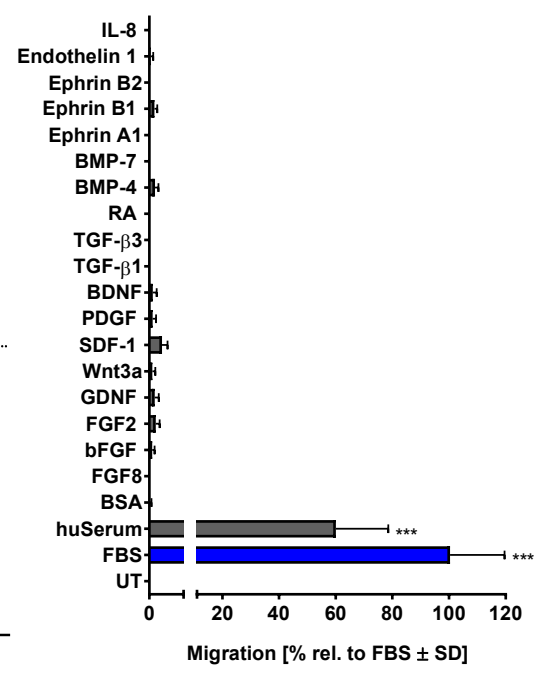

Figure 1. Characterization of the chemotaxis-promoting factor of bovine serum. (A) Graphical representation of the neural crest-membrane translocation (NC-MT) assay principle. Cells were plated into cell culture inserts equipped with a porous membrane at the bottom. This allows the addition of different amounts of potential chemoattractants to the reservoir and insert compartments. A chemoattractant gradient is thereby formed in the pores of the membrane. (B) FBS is shown as an example of a compound that triggers NCCs to migrate through the pores and to settle on the lower surface of the membrane. Example images show stained cells that have translocated and also visualizes the pores, which have a nominal diameter of $8 \mu \mathrm{m}$. Cells are shown by arrow heads, and pores are indicated by arrows. Scale bar: $25 \mu \mathrm{m}$. (C) The NC-MT assay was performed with 5\% FBS added either to the reservoir, to the insert or into both compartments. After $6 \mathrm{~h}$, cells on the lower membrane surface were fixed and stained, and then the number of migrated cells was counted. Data were normalized to the maximal migration condition and are shown as means $\pm \mathrm{SD}$ from three independent experiments. ${ }^{* * *} p<$ 0.001, ns: not significant as determined by one-way ANOVA followed by Dunnett's post hoc test (compared to untreated control). (D) Several potential chemoattractants were tested in the NC-MT assay. The concentrations were $5 \%$ for fetal bovine serum (FBS), human serum (huSerum) and bovine serum albumin (BSA); $20 \mathrm{ng} / \mathrm{mL}$ for fibroblast growth factor 2 and 8 (FGF2/FGF8), glial cell line-derived neurotrophic factor (GDNF), stromal cell-derived factor 1 (SDF-1) and ephrin A1, $\mathrm{B} 1$ and B2; $50 \mu \mathrm{g} / \mathrm{mL}$ for basic fibroblast growth factor (bFGF); $10 \mathrm{ng} / \mathrm{mL}$ for Wnt3a; $50 \mathrm{ng} / \mathrm{mL}$ for platelet-derived growth factor (PDGF); $100 \mathrm{ng} / \mathrm{mL}$ for brain-derived neurotrophic factor (BDNF); $1 \mathrm{ng} / \mathrm{mL}$ for transforming growth factor $\beta 1$ and 3 (TGF- $\beta$ 1/TGF- $\beta$ 3); $1 \mu \mathrm{M}$ for retinoic acid (RA); $3 \mathrm{ng} / \mathrm{mL}$ for bone morphogenetic protein 4 and 7 (BMP-4/BMP-7); 10 $\mathrm{nM}$ for endothelin 1; $100 \mathrm{ng} / \mathrm{mL}$ for interleukin-8 (IL-8). UT: untreated. Data are normalized to FBS data and are shown as means $\pm \mathrm{SD}$ from at least two independent experiments. ${ }^{* * *} p<0.001$ as determined by one-way ANOVA followed by Dunnett's post hoc test (compared to untreated control). (E) Before being used as a chemoattractant in the lower (reservoir) chamber (at 5\%), FBS was digested with $0.5 \%$ pepsin at $\mathrm{pH}=2.0$. The control sample (-pepsin) was run through the same procedure (acidification, $1 \mathrm{~h}$ incubation, buffering to $\mathrm{pH}=7.0$ ) but without pepsin. Activity was determined in the NC-MT assay. Data are normalized to untreated FBS and are shown as means \pm SD from three independent experiments. ${ }^{* * *} p<0.001$, ns: not significant as determined by one-way ANOVA followed by Dunnett's post hoc test (compared to 
untreated control). (F) FBS samples were heat treated under different conditions and tested afterwards at $5 \%$ concentration in the NC-MT assay for chemotactic activity. Data are normalized to FBS and shown as means \pm SD from three independent experiments. ${ }^{* * *} p<0.001$, ns: not significant as determined by one-way ANOVA followed by Dunnett's post hoc test (compared to untreated control).

The main component of FBS and huSerum, the protein albumin, had no chemotactic activity. However, FBS contains many other proteins and also many small molecules. To obtain an idea of whether a protein is responsible for CTA, we treated FBS in different ways before it was tested for chemoattractant activity. Digestion of proteins by pepsin and protein-denaturation by heating to $70{ }^{\circ} \mathrm{C}$ both inactivated the putative chemotaxispromoting factor (Figure 1E,F). From this, we conclude that with a high probability the CTA is at least in part a protein.

\subsection{Characterization of the Chemotaxis-Triggering Factor in FBS}

As the chemotaxis-triggering factor in FBS is most likely a protein, we wondered whether it could be enriched or even be purified. For this purpose, several traditional protein separation strategies were combined in a general strategy. As albumin accounts for $>60 \%$ of the protein in FBS, it was important to find a step capable of removing it early on. Different fractional precipitation approaches were tested and optimized sequential acetone precipitation was found to be optimal for albumin removal. The second enrichment step was a fast protein liquid chromatography (FPLC) purification with an anion exchange column (HiTrap Q FF). The individual fractions were tested in the NC-MT assay, and those that triggered increased NCC migration were combined, desalted and further purified with another anion exchange column (HiTrap Q HP) (Figure 2A). The fractions were tested directly in the NC-MT assay for their migration-increasing activity (Figure S1B), and we tried to store these for further use. We found that all highly purified fractions lost their CTA bioactivity within $24 \mathrm{~h}$. Multiple approaches of protein stabilization and improved storage were tried. However, we did not identify a procedure that allowed the chemotaxis-promoting factor to be stored overnight once it was highly purified. One potential explanation for this loss of activity is that the "CTA protein" is stabilized by another protein, which is lost upon purification. Due to this situation, the purification and bioactivity testing always had to be performed within one day.

As an alternative approach to protein chromatography, we used ultrafiltration membranes to obtain an indication of the size range of the CTA contained in FBS. We found that the chemoattractant behaves like a protein with an MW of 50-100 kDa (Figure 2B). Mass spectrometric (MS) analysis of the most active fraction purified from the second anion exchange column suggested serpin A1, which has a size of $52 \mathrm{kDa}$, as a potential candidate (Figure S1C). Detailed follow-up and confirmation experiments showed that serpin A1 does not have chemotaxis-promoting activity (Figure S1D). Analysis of MS spectra showed that the fraction containing serpin A1 contained at least 20 further proteins (not shown). For this reason, the CTA protein may be easily masked by one of the highly abundant serum proteins, such as serpins [57]. The stepwise purification, including acetone precipitation and two anion exchangers, enabled a 1000-fold purification of the chemotaxis-promoting factor compared to the starting material (Figure 2C and Figure S1A). This strong enrichment was not sufficient for MS identification, as even the active fractions contained complex protein mixtures. To solve this problem, additional and more efficient chromatographic columns are necessary. As an alternative strategy, we considered a less complex starting material. 
A

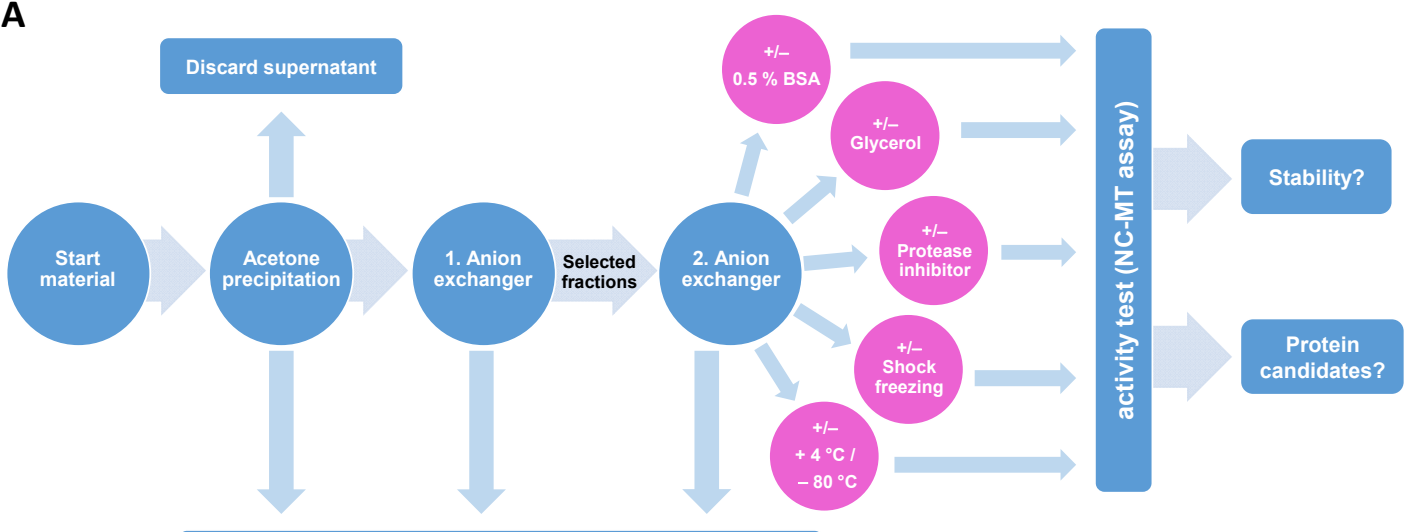

activity test (NC-MT assay) $\rightarrow$ further selection

B

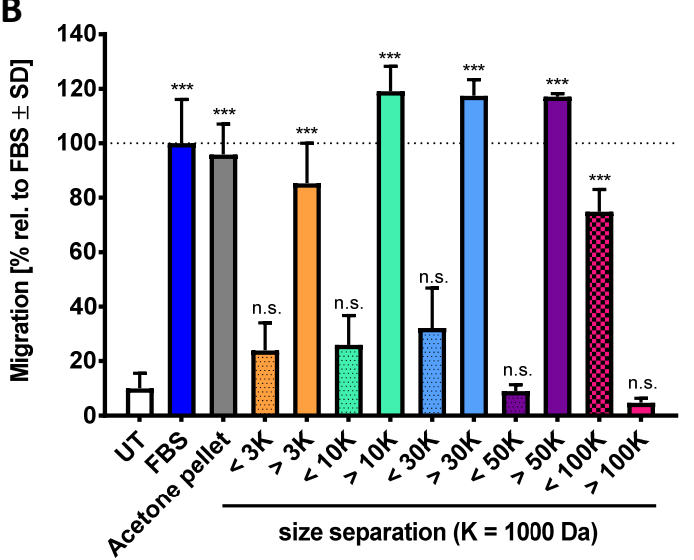

C

\begin{tabular}{|c|c|c|}
\hline Purification Step & $\begin{array}{r}\text { Specific } \\
\text { Activity } \\
{[\text { U/mg] }}\end{array}$ & $\begin{array}{c}\text { Purification } \\
\text { Factor }\end{array}$ \\
\hline Initial FBS & 3.3 & - \\
\hline Acetone precipitation & 16 & 4.7 \\
\hline First anion exchanger & 1190 & 360 \\
\hline $\begin{array}{c}\text { Second anion } \\
\text { exchanger }\end{array}$ & 3280 & 990 \\
\hline
\end{tabular}

Figure 2. Characterization and purification of the chemotaxis-promoting factor of fetal bovine serum (FBS). (A) Scheme for the enrichment strategy of chemotactic factors from FBS. The activity was measured with the NC-MT assay after each purification step (blue circles). Active fractions from the first anion exchanger (HiTrap Q FF) were combined, desalted and loaded onto the second anion exchange column (HiTrap Q HP). After the last purification step, samples were stored under different conditions (pink circles) for $24 \mathrm{~h}$. Afterwards, the activity of the samples was tested in the NC-MT assay. (B) FBS was precipitated by acetone, and the protein pellet was dissolved and applied to ultrafiltration membranes with different cut-offs. Flow through $(<)$ and filtrate $(>)$ were then tested in the NC-MT-HTS assay. Data are normalized to non-fractionated FBS and shown as means \pm SD from three independent experiments. ${ }^{* * *} p<0.001$, ns: not significant as determined by one-way ANOVA followed by Dunnett's post hoc test (compared to untreated control). (C) The specific activity and the purification factor were determined after each purification step. The used anion exchangers differ in their resin material, loading capacity and flow rates. The most active fractions of each anion exchanger were used for calculations. Data are given relative to the starting material (=FBS).

\subsection{Chemotaxis-Triggering Activity Present in Conditioned Medium of HepG2 Cells}

We reasoned that all proteins present in serum are produced by cells. Moreover, our screen for CTA sources had shown that human serum is also bioactive (Figure 1D). Therefore, we set up the hypothesis that some human cells should produce the protein responsible for NC chemoattractant activity. In order to test this, we used a small cell panel, including HepG2 hepatoma cells, MDA-MB-231 breast adenocarcinoma cells, HeLa cervical cancer cells, HEK-239 human embryonic kidney cells and SH-SY5Y neuroblastoma cells to examine the production of CTA (Figure 3A). In a first approach, we used conditioned medium (CM) from all cell lines in the NC-MT assay. The data showed that HepG2 and MDA cells are potent producers of a CTA, HeLa and HEK-239 cells were moderate producers, and SH-SY5Y CM was devoid of any activity. In a second, independent experimental approach, we then confirmed these findings by culturing the cell lines in the lower compartment of the chemotaxis assay setup. SH-SY5Y neuroblastoma 
cells had no chemoattractant activity at all, i.e., their presence did not trigger any of the NCCs to move through the membrane. This showed that human cells (as such) do not have unspecific chemoattractive effects if co-cultured in the NC-MT assay. The cells that were chemoattractive for NCCs had a potency order similar to the one found for their CM (Figure 3A). Thus, some cells seem to secrete a protein that is chemoattractive for NCCs. We decided to focus on HepG2 as producing cell line. For initial characterization, stability studies were performed on HepG2 CM. Data from these experiments showed that the CTA in this material is completely inactivated by pepsin digestion and by moderate heating $\left(70{ }^{\circ} \mathrm{C}\right.$ ) (Figure 3B,C). These results confirmed that the CTA of HepG2 CM is a protein.

Based on this knowledge, a stepwise purification approach was started. Acetone precipitation was used as the first step, as it also had a concentrating and desalting function. Various chromatographic columns were then used. A cation exchanger (HiScreen Capto SP ImpRes) proved to be the most efficient, and it yielded highly enriched CTA (Figure S2B). The fractions with the highest migration-increasing activity in the NC-MT assay (Figure S2A) were used for MS analysis. Fibronectin and apolipoprotein- $\mathrm{H}$ were consistently identified in the most active fractions (Figure S2C,D). We speculated that a second chromatographic column would remove one of these two proteins and thus give an indication on which one may trigger migration. Therefore, the active fractions of the cation exchange column were combined, desalted and further purified by an anion exchange column (HiTrap Q HP). The individual fractions were tested in the NC-MT assay, and only one fraction triggered NCC migration (Figure 3D). Polyacrylamide gel size separation of the CTA containing a fraction resulted in two major protein bands (Figure 3F), and MS analysis identified them consistently as fibronectin and serum albumin/alpha-fetoprotein (AFP) (Figure 3G). As apolipoprotein-H was not present in the active fraction after the second chromatographic purification step, we retained fibronectin as a promising candidate and excluded apolipoprotein-H. Serum albumin and AFP share 39\% primary structure homology and have the same MW of about $69 \mathrm{kDa}$ [58]. Therefore, MS analysis does not sufficiently distinguish between albumin and AFP. However, it was shown that serum deprivation of HepG2 cells increased the production of AFP compared to albumin [59]. Moreover, we had found that purified albumin is not chemoattractive. Therefore, we took AFP as another promising CTA candidate. Our assumption was further supported by the identification of AFP in HepG2 CM via Western blot (data not shown).

For further narrowing down the identity of the CTA, we decided to focus on the two most abundant proteins present in the active fraction, fibronectin and AFP. To probe the role of fibronectin, it was removed from HepG2 $\mathrm{CM}$ by affinity precipitation, using gelatin sepharose beads (Figure S3C,D). Testing in the NC-MT assay showed that HepG2 CM without fibronectin has the same migration-increasing effect on NCCs as HepG2 CM with fibronectin (Figure S3B). We, therefore, excluded fibronectin as the potential chemoattractant factor in HepG2 CM. Two further proteins identified by MS were excluded as likely contaminants: Dermcidin is present in human sweat and is therefore often found in MS samples (Figure 3G). Additionally, the nuclear lamina protein lamin-B1 was discarded as a likely candidate (Figure 3G). As SH-SY5Y neuroblastoma cells had no chemoattractant activity at all in the NC-MT assay (Figure 3A and Figure S4A), and CM produced from these cells did not contain albumin or AFP (Figure S4B), we expressed recombinant AFP in the neuroblastoma cell line. Engineered SH-SY5Y cells produced AFP (Figure S4D,E) but did not show chemotactic activity in the NC-MT assay (Figure S4C). From these data, we concluded that AFP is not the chemotaxis-promoting factor in HepG2 CM. Thus, our purification approach, which resulted in a 5000-fold enrichment of the starting material (Figure 3E), did not allow the CTA identification. However, we were able to enrich a definitely human NCC chemotaxis factor to a high degree. Active HepG2 fractions contained clearly less protein than active FBS fractions, but the supernatant production was very resource-requiring. Moreover, it cannot be excluded that cancer cells produce a factor that is not physiologically relevant. Therefore, we considered other sources. 


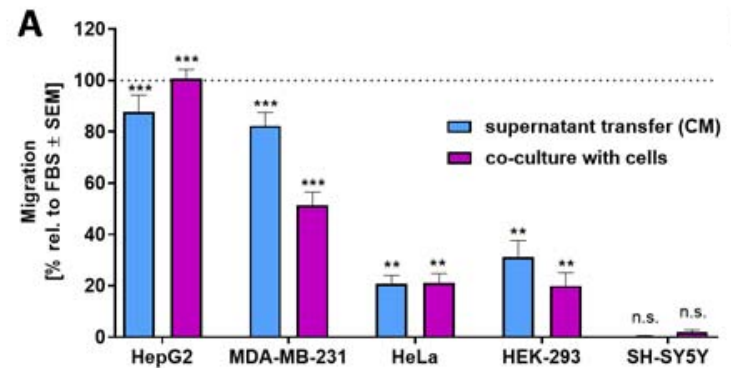

D

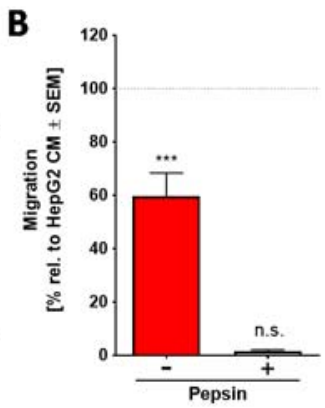

C

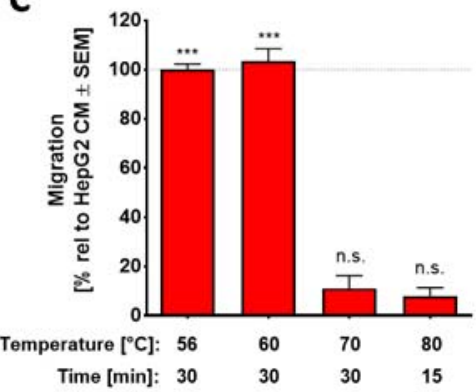

$\mathbf{E}$

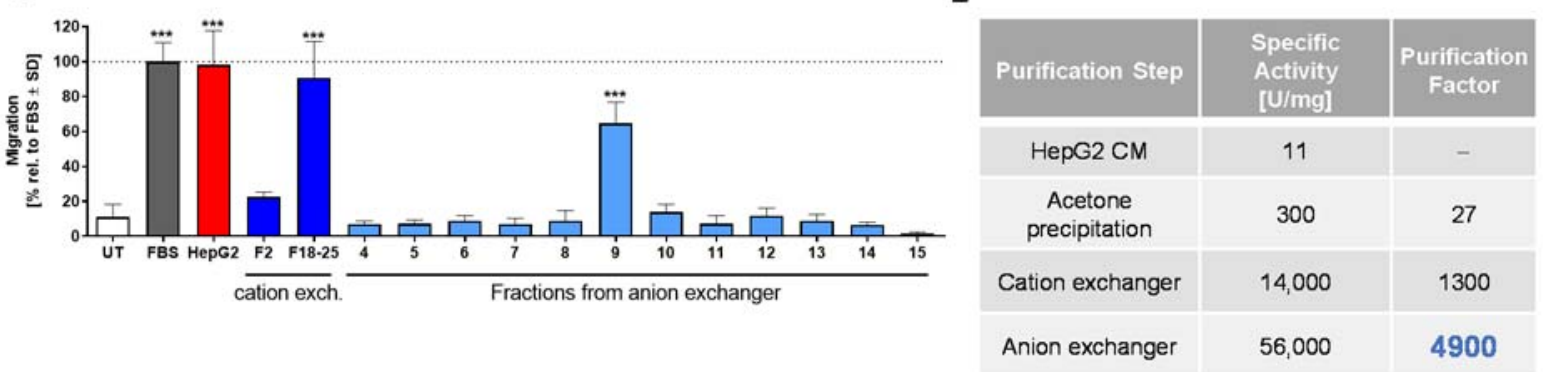

$\mathbf{F}$

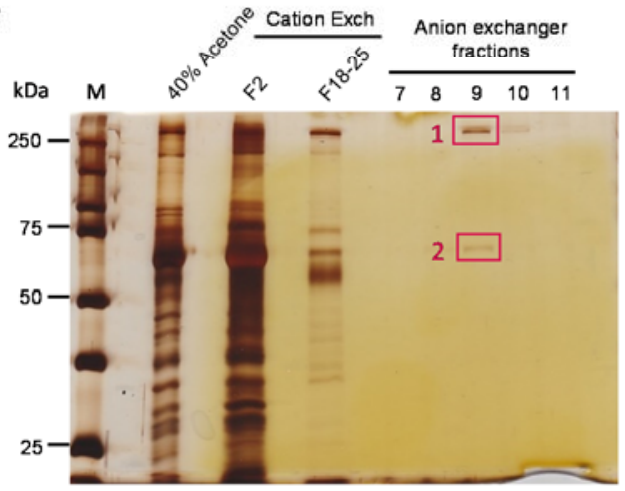

G

\begin{tabular}{|c|c|c|c|c|}
\hline 1 Description & Score & Coverage & $\begin{array}{c}\text { \# Unique } \\
\text { Peptides }\end{array}$ & MW [kDa] \\
\hline Fibronectin & 2447.0 & 19.7 & 36 & 272.2 \\
\hline Dermcidin & 112.0 & 20.0 & 2 & 11.3 \\
\hline 2 Description & Score & Coverage & $\begin{array}{c}\text { \# Unique } \\
\text { Peptides }\end{array}$ & MW [kDa] \\
\hline Serum albumin & 2707.0 & 53.4 & 32 & 69.3 \\
\hline Alpha-fetoprotein & 2506.0 & 51.6 & 26 & 68.6 \\
\hline Lamin-B1 & 719.0 & 24.2 & 14 & 66.4 \\
\hline
\end{tabular}

Figure 3. Characterization of the chemotaxis-promoting factor in HepG2 conditioned medium (CM). (A) Production of chemoattractant factors by human cell lines was examined by two experimental setups: the use of conditioned medium (CM) and co-culture. For the transfer of CM, the indicated cell lines were cultured in the medium with $0 \%$ FBS for $48 \mathrm{~h}$. The medium supernatant from these cultures was collected and then used to fill the (lower) reservoirs of the NC-MT assay. The upper insert was filled with NCCs and fresh (unconditioned) medium. For co-culture experiments, cells of the indicated cell lines were grown at the bottom of the reservoir. At the start of the experiment, they received fresh medium with $0 \%$ FBS, and $48 \mathrm{~h}$ later, NCCs were added to the inserts above the cell lines in fresh medium (upper compartment). In both cases, NCCs were allowed to migrate for $6 \mathrm{~h}$, before the number of cells reaching the lower membrane side was quantified. Data are normalized to the migration triggered by $5 \%$ FBS. They are shown as means \pm SEM from at least three independent experiments. ${ }^{* *} p<0.01,{ }^{* * *} p<0.001$, ns: not significant as determined by one-way ANOVA followed by Dunnett's post hoc test (compared to untreated control). (B) Before use as a chemoattractant in the lower (reservoir) chamber, HepG2 CM was digested with pepsin, as in Figure 1E. Data are normalized to HepG2 CM and are shown as means \pm SD from three independent experiments. ${ }^{* *} p<0.001$, ns: not significant as determined by one-way ANOVA followed by Dunnett's post hoc test (compared to untreated control). (C) HepG2 CM samples were heat treated under different conditions and tested afterwards at 5\% concentration in the NC-MT assay for chemotactic activity. Data are normalized to HepG2 CM and shown as means $\pm \mathrm{SD}$ from three independent experiments. ${ }^{* * *} p<0.001$, ns: not significant as determined by one-way ANOVA followed by Dunnett's post hoc test (compared to untreated control). (D) The chemotaxis-triggering factor in HepG2 CM was purified via acetone precipitation followed by a cation exchange column (HiScreen Capto SP ImpRes) and an anion exchange column (HiTrap Q HP). Fraction 2 (F2) and the combined fractions F18-25 (F18-25) from the cation exchanger as well as fractions $4-15$ from the anion exchanger were tested at a final concentration of $20 \%$ ( $80 \%$ fresh medium) in the NC-MT-HTS assay. As a positive control, 5\% FBS and 100\% HepG2 CM were used. UT: untreated. Data are means \pm SD of three independent experiments. ${ }^{* * *} p<0.001$ as determined by one-way ANOVA followed by Dunnett's post hoc test 
(compared to untreated control). (E) The specific activity and the purification factor were determined after each purification step. (F) Samples from acetone precipitation (40\% acetone), fraction 2 (F2) and combined fractions 18-25 (F18-25) from the cation exchanger as well as fractions 7-11 from the anion exchanger were separated on a 10\% SDS gel, and bands were visualized by silver staining. Bands cut out for MS analysis are marked in red. 1: fibronectin, 2: alpha-fetoprotein. (G) Proteins in fraction 9 from the anion exchanger were separated on a 10\% SDS gel, and two bands were cut out for mass spectrometry (MS) analysis. The table represents the MS result of bands 1 and 2 of fraction 9, detecting fibronectin and alpha-fetoprotein as the most abundant proteins. MS analysis was performed from two independent experiments with the same results.

\subsection{Human Platelet Lysate as Animal-Free CTA Alternative}

Human platelet lysate is a high-quality human-derived product known to be rich in growth factors. It appeared as optimal alternative starting material, as it is commercially available. In a pilot experiment, we produced a small amount of huPL ourselves and observed potent bioactivity in the NC-MT assay (not shown). To follow up on this, we obtained huPL from various suppliers. We were surprised to observe that the huPL contained large amounts of albumin (Figure S5A). Our investigations showed that plasma is added to all commercial huPLs. The suppliers argued that this is necessary to stabilize the platelet factors and to guaranty optimal cell growth when huPL is used as cell culture additive $[60,61]$. When we tested different lots of commercially available huPLs in the NC-MT assay, we found that this material potently triggered NCC migration (Figure 4A). In the next step, we used our established procedures to verify that a protein of the lysate is responsible for chemotaxis. Data from these experiments showed that the CTA in huPL is inactivated by pepsin digestion and by heating (Figure 4B,C). We, therefore, concluded that the chemotaxis-promoting factor in huPL is a protein similar to the factor present in FBS and HepG2 CM. For purification of the CTA, we optimized the strategy and started with a chromatographic purification step using the HiScreen Capto SP ImpRes cation exchange column and Figure S5B. The acetone precipitation was performed afterwards on the pooled active fractions obtained. This way, the pellet could be frozen and stored at $-20^{\circ} \mathrm{C}$. Through this improved procedure, it was no longer necessary to perform all purification steps within one day. Additionally, many acetone pellets could be combined, and a large batch could be produced for further purification. A disadvantage of this process was that the pellet was hard to dissolve, and some material was lost. By running the re-dissolved material over an anion exchange column (HiTrap Q HP), the CTA could eventually be purified up to 2000-fold, compared to the starting material (Figure 4E). 
A

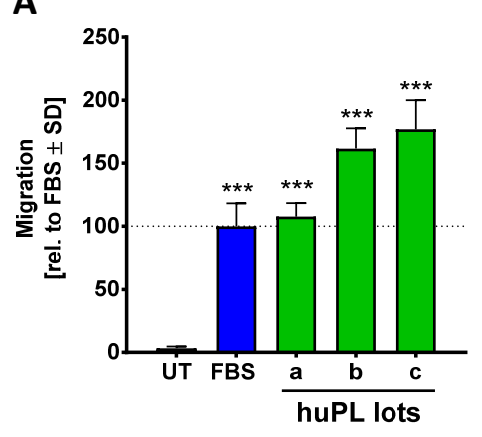

D

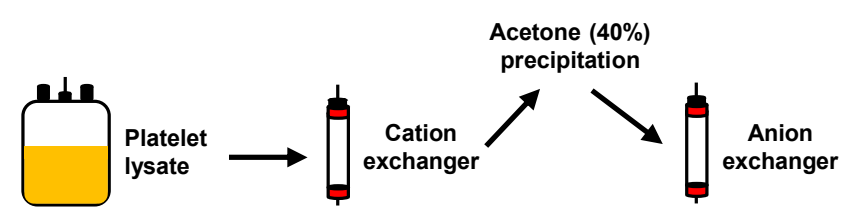

B

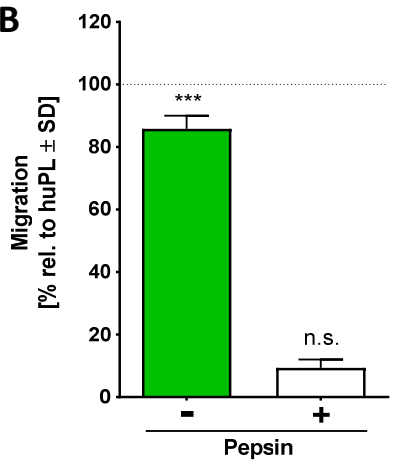

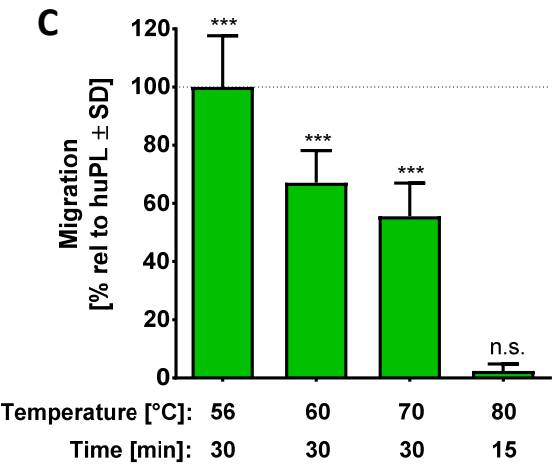

E

\begin{tabular}{|c|c|c|}
\hline Purification Step & $\begin{array}{c}\text { Specific Activity } \\
{[\text { U/mg] }}\end{array}$ & $\begin{array}{c}\text { Purification } \\
\text { Factor }\end{array}$ \\
\hline Initial huPL & 48 & - \\
\hline Cation exchanger & 2000 & 40 \\
\hline Acetone precipitation & 24,000 & 500 \\
\hline Anion exchanger & 90,000 & 2000 \\
\hline
\end{tabular}

Figure 4. Characterization of the chemotaxis-promoting factor from human platelets. (A) Several commercially available huPLs (lots a-c) were tested at a final concentration of 5\% in the NC-MT assay. Heparin (at a final concentration of $2 \mathrm{U} / \mathrm{mL}$ ) was added to lots $b$ and $c$ to prevent coagulation of the medium. FBS (5\%) was used as positive control. Data are normalized to FBS and are shown as means \pm SD from three independent experiments. ${ }^{* * *} p<0.001$ as determined by one-way ANOVA followed by Dunnett's post hoc test (compared to untreated control). (B) Before being used as a chemoattractant in the lower (reservoir) chamber (at $5 \%$ ), huPL was digested with $0.5 \%$ pepsin (as in Figure 1E). Data are normalized to huPL and are shown as means \pm SD from three independent experiments. ${ }^{* * *} p<0.001$, ns: not significant as determined by one-way ANOVA followed by Dunnett's post hoc test (compared to untreated control). (C) huPL samples were heat treated under different conditions and tested afterwards at 5\% concentration in the NC-MT assay for chemotactic activity. Data are normalized to huPL and shown as means \pm SD from three independent experiments. ${ }^{* *} p<0.001$, ns: not significant as determined by one-way ANOVA followed by Dunnett's post hoc test (compared to untreated control). (D) Scheme for the enrichment strategy for chemotactic factors from human platelet lysate (huPL). Platelet lysate was fractionated on a cation exchange column (HiScreen Capto SP ImpRes), followed by acetone precipitation and analysis of the pellet material on an anion exchange column (HiTrap Q HP). (E) The specific activity and the purification factor were determined after each purification step.

\subsection{Time-Lapse Analysis of the Chemotactic Activity of FBS, HepG2 CM and huPL}

Having established three ways to obtain a potent NCC chemotactic factor in a populationbased assay (NC-MT), we were interested in obtaining additional and more direct proof of chemotactic activity on individual cells. The NC-MT assay determines the number of migrated cells at the end of the assay, and cells are not observable during the migration. To avoid these issues, we performed the $\mu$-slide chemotaxis assay. This setup uses a complex cell culture format (produced by ibidi), in which cells can be placed in a stable chemical gradient and observed over several hours (Figure 5A and Figure S6A). The cells were observed via time-lapse imaging, and the migration tracks of individual cells were visualized. Initial controls showed that NCC migrated in all directions when there was no chemoattractant present (Figure 5B left). When cells were exposed to the same concentration of a chemoattractant on both sides, they migrated towards both stimuli with about the same frequency (Figure 5B right). For classical chemotaxis testing, only one reservoir was filled with a chemoattractant (FBS, HepG2 CM or huPL) so that cells were within a stable gradient. Under these conditions, they migrated towards the higher concentration of the chemoattractant (Figure 5C). 

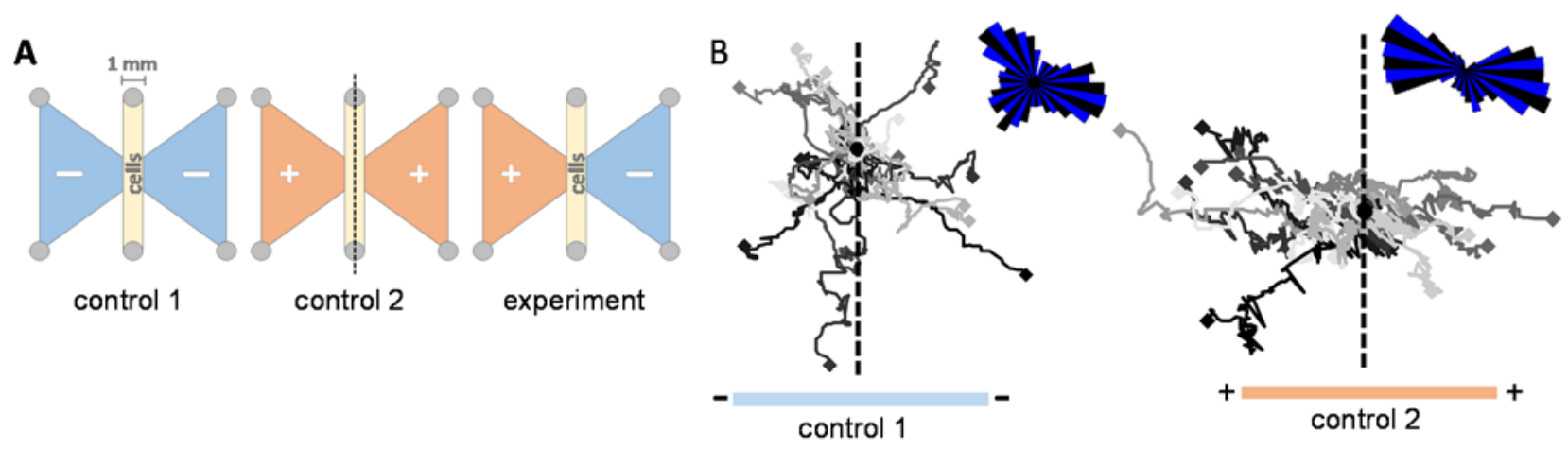

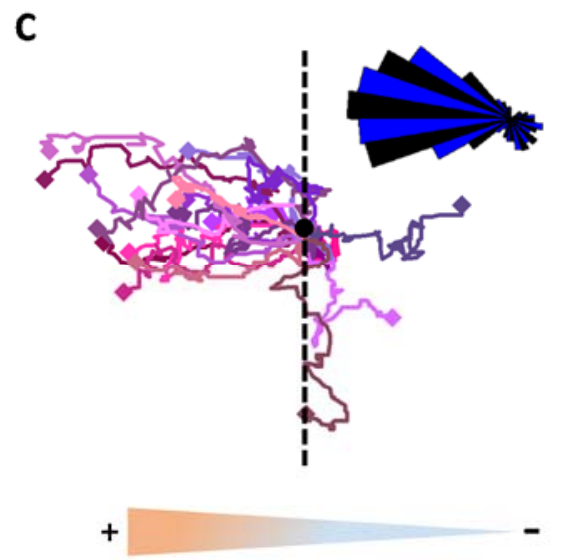

FBS
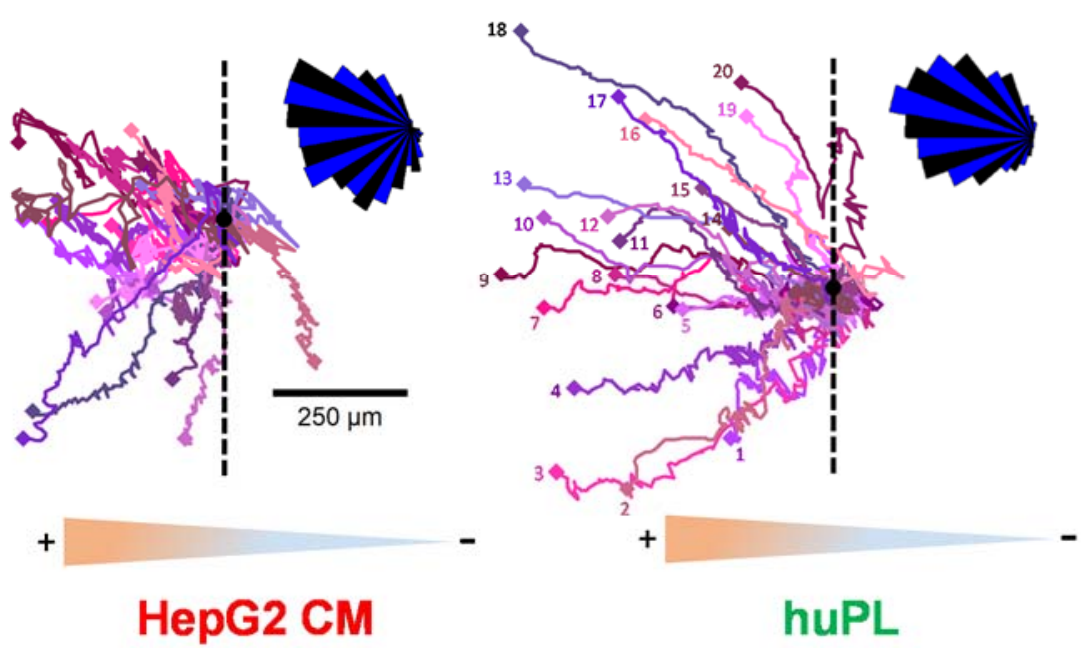

Figure 5. Tracking of single cells to compare the chemotactic activity of FBS, huPL and HepG2 CM. (A) Graphical illustration of the $\mu$-slide chemotaxis assay setup, as seen from above (ibidi). Cells were seeded in the $1 \mathrm{~mm}$ broad gap between the reservoirs (oblong middle compartment). Reservoirs on both sides (shown as triangles) were either filled with medium $(-)$ or chemoattractant dissolved in medium (+). (B) Representative cell trajectories (recorded for $24 \mathrm{~h}$ ) of $20 \mathrm{NCCs}$ with medium in both reservoirs (control 1, left) or FBS (5\%) in both reservoirs (control 2, right). For the quantification of the migration, the chamber was placed onto a microscope stage, and cell movement was observed by time-lapse video imaging. The black dot is the starting point of all cells in a re-normalized coordinate system (overlay of all cell starting points). The dashed line was inserted as a visual aid to symbolize the "watershed" of the gradient. The density plot in the upper right corner was constructed by separating the migration area into 36 sectors (each $10^{\circ}$ wide) starting from the migration origin. The length of the segments indicates the distribution of cell counts inside the sectors. For visualization reasons, sectors were alternatingly stained blue and black. (C) Representative cell trajectories (recorded for $24 \mathrm{~h}$ ) of 20 NCCs with medium in the right reservoir and FBS, huPL or HepG2 CM filled in the left reservoir. Numbers for each individual cell are only indicated in the right figure for graphical reasons.

The software provided by the assay chamber supplier allowed quantification of migration parallel or perpendicular to the gradient (Figure S6A). Chemotaxis is defined by this program as a form of migration that is more effective parallel to the gradient than perpendicular to it. The addition of FBS, HepG2 CM or huPL to one reservoir led to clear chemotaxis (Figure S6B). The results confirmed that FBS, HepG2 CM and huPL trigger chemotaxis in individual NCCs. Moreover, NCCs in a HepG2 CM or huPL gradient also migrated longer distances and faster compared to the control cells (Figure S6D). In conclusion, FBS, HepG2 CM and huPL are verified sources of CTA for NCCs.

\section{Materials and Methods}

\subsection{Neural Crest Cell Differentiation}

For the differentiation of human NCCs, several induced pluripotent stem cell (iPSC) lines (IMR90_clone_\#4 (WiCell, Madison, WI, USA), SIGi001-A (Sigma, Steinheim, Germany) and SBAD2 (derived and characterized at the University of Newcastle from Lonza 
fibroblasts CC-2511, Lot 293971 with the tissue acquisition number 24245 [62]) were tested. The differentiation to NCCs was performed according to a modified protocol of Mica et al. (2013) [63]. IPSCs were maintained on human Laminin-521 (BioLamina, Sundbyger, Sweden) coating in essential 8 (E8) medium (DMEM/F12 supplemented with 15 mM Hepes (Gibco/Fisher Scientific, Hampton, NH, USA), $16 \mathrm{mg} / \mathrm{mL}$, L-ascorbic-acid, $0.7 \mathrm{mg} / \mathrm{mL}$ sodium selenite, $20 \mu \mathrm{g} / \mathrm{mL}$ insulin, $10 \mu \mathrm{g} / \mathrm{mL}$ holo-transferrin (all from Sigma, Steinheim, Germany), $100 \mathrm{ng} / \mathrm{mL}$ bFGF (Thermo Fisher Scientific, Waltham, MA, US) and $1.74 \mathrm{ng} / \mathrm{mL}$ TGFb (R\&D Systems, Minneapolis, MN, USA). For differentiation into NCCs, iPSCs were plated on Matrigel $^{\mathrm{TM}}$ (Corning, Glendale, AZ, USA) coated 6-well plates at a density of 100,000 cells $/ \mathrm{cm}^{2}$ in E8 medium containing $10 \mu \mathrm{M}$ ROCK-inhibitor (Y-27632 (Tocris, Bristol, UK)). After one day, cells reached a confluency of 70-80\%, and differentiation was initiated (day 0) by a medium change to KSR medium (Knock out DMEM, 15\% knock out serum replacement, 1\% GlutaMax, 1\% MEM NEAA solution and $50 \mu \mathrm{M}$ 2-mercaptoethanol (all from Gibco/Fisher Scientific, Hampton, NH, USA)) supplemented with $20 \mathrm{ng} / \mathrm{mL}$ Noggin (R\&D Systems, Minneapolis, MN, USA) and $10 \mu \mathrm{M}$ SB431542 (Tocris, Bristol, UK). From day 2 on, cells were treated with $3 \mu \mathrm{M}$ CHIR 99021 (Axon Medchem, Reston, VA, USA). Noggin and SB431542 were withdrawn at day 3 and 4, respectively. Beginning at day 4, the KSR medium was gradually replaced by $25 \%$ increments of N2-S medium (DMEM/F12, 1\% GlutaMax (both from Gibco/Fisher Scientific, Hampton, NH, USA), $1.55 \mathrm{mg} / \mathrm{mL}$ glucose, $0.1 \mathrm{mg} / \mathrm{mL}$ apotransferin, $25 \mu \mathrm{g} / \mathrm{mL}$ insulin, $20 \mathrm{nM}$ progesterone, $100 \mu \mathrm{M}$ putrescine and $30 \mathrm{nM}$ selenium (all from Sigma, Steinheim, Germany)). Cells were collected at day 11, then resuspended in N2-S medium supplemented with $20 \mathrm{ng} / \mathrm{mL}$ EGF and $20 \mathrm{ng} / \mathrm{mL}$ FGF2 (both from R\&D Systems, Minneapolis, MN, USA) and seeded as droplets $(10 \mu \mathrm{L})$ on poly-L-ornithine (PLO)/laminin/fibronectin-coated (all from Sigma, Steinheim, Germany) $10 \mathrm{~cm}$ dishes. Cells were expanded by weekly splitting. From now on, seeding as droplets was not necessary, and the medium was changed every second day. After 35-39 days, cells were cryopreserved at a concentration of $4 \times 10^{6}$ cells $/ \mathrm{mL}$ in $90 \% \mathrm{~N} 2-\mathrm{S}$ medium and 10\% dimethyl sulfoxide (DMSO) (Merck Millipore, Burlington, MA, USA) until further use.

\subsection{Migration Assay (cMINC)}

The circular migration inhibition of neural crest cell (MINC) assay was performed as described earlier [50]. Briefly, silicone stoppers (Platypus Technologies, Madison, WI, USA) were placed centrally into each experimental well of a 96-well polystyrene plate (Corning, Glendale, AZ, USA) coated with $10 \mu \mathrm{g} / \mathrm{mL}$ poly-L-ornithine (PLO), $1 \mu \mathrm{g} / \mathrm{mL}$ fibronectin and $1 \mu \mathrm{g} / \mathrm{mL}$ laminin (all from Sigma, Steinheim, Germany). Cells were seeded around the stoppers at a density of 95,000 cells $/ \mathrm{cm}^{2}$. The following day, stoppers were removed to allow cells to migrate into the cell-free central area, and the medium was refreshed. To test the effect of toxicants on NCC motility, 5x concentrated toxicant solution was added to the medium $24 \mathrm{~h}$ after stopper removal. After another $24 \mathrm{~h}$, cell viability and migration endpoints were monitored. For this, cells were stained with $1 \mu \mathrm{g} / \mathrm{mL}$ HOECHST-33342 and $533 \mathrm{nM}$ calcein-AM (both from Sigma, Steinheim, Germany), and image acquisition was performed using a Cellomics ArrayScan VTI imaging microscope (Thermo Fisher, Pittsburgh, PA, USA). HOECHST-33342 and calcein double-positive cells were defined as viable cells and determined by an automated algorithm described earlier [64,65]. For the quantification of migration, a free software tool (http:/ / invitrotox.uni-konstanz.de/RA/, accessed on 14 May 2021) was used to calculate the original stopper position and determine the number of HOECHST-33342 and calcein double positive cells within the migration area as described earlier [50]. Viability and migration were normalized to untreated or solvent control (0.1\% DMSO).

\subsection{Neural Crest Membrane Translocation (NC-MT) Assay}

For the NC-MT assay, Transwell ${ }^{\circledR} 24$ well permeable supports (pore size $8 \mu \mathrm{m}$, polycarbonate membrane, Corning, Glendale, Arizona, USA, catalog no. 3422) were used. NCCs were seeded at a density of 50,000 cells per insert $\left(150,000\right.$ cells $\left./ \mathrm{cm}^{2}, 100 \mu \mathrm{L}\right)$ in 
N2-S medium supplemented with $20 \mathrm{ng} / \mathrm{mL}$ EGF and $20 \mathrm{ng} / \mathrm{mL}$ FGF2 (both from R\&D Systems, Minneapolis, MN, USA) into the upper chamber. Test compounds were added in the stated concentration to the lower chamber $(650 \mu \mathrm{L})$. The cells were allowed to migrate for $6 \mathrm{~h}$ at $37^{\circ} \mathrm{C}$ and $5 \% \mathrm{CO}_{2}$. After incubation, the medium was aspirated from the inserts and reservoirs, and the upper side of each insert was gently swabbed, using cotton-swabs, to remove cells that had not migrated through the membrane. Reservoirs and inserts were washed once with phosphate-buffered saline (PBS), and afterwards, the migrated cells on the membrane were fixed with $3.7 \%$ formaldehyde $\left(v / v\right.$ in $\left.\mathrm{H}_{2} \mathrm{O}\right)$ and stained with crystal violet for $15 \mathrm{~min}$. Subsequently, the inserts were thoroughly rinsed with water and dried for at least $24 \mathrm{~h}$. Five non-overlapping pictures per condition were taken with an Axio Observer Z1 microscope (Zeiss, Oberkochen, Germany) to evaluate the number of migrated cells. The number of migrated cells was normalized to that of cells stimulated with FBS.

For the NC-MT-HTS assay, the Transwell ${ }^{\circledR}$ high throughput screening system (pore size $8 \mu \mathrm{m}$, polyester membrane, Corning, Glendale, AZ, USA, catalog no. 3384) was used. It consists of 96 wells of permeable inserts connected by a rigid tray and a 96-well receiver plate. Cells were seeded at a density of 25,000 cells per insert $\left(175,000\right.$ cells $\left./ \mathrm{cm}^{2}, 50 \mu \mathrm{L}\right)$ into the upper chamber. Test compounds were added in the stated concentration to the lower chamber $(150 \mu \mathrm{L})$. The cells were allowed to migrate for $6 \mathrm{~h}$ at $37^{\circ} \mathrm{C}$ and $5 \% \mathrm{CO}_{2}$. After incubation, the medium was aspirated from inserts and reservoirs, and both were washed once with PBS. Reservoirs were filled with $150 \mu \mathrm{L}$ EDTA solution containing $130 \mathrm{nM}$ calcein-AM (Sigma, Steinheim, Germany) and incubated for $30 \mathrm{~min}$ at $37^{\circ} \mathrm{C}$ and $5 \%$ $\mathrm{CO}_{2}$. Plates were then centrifuged for $4 \mathrm{~min}$ at $350 \times \mathrm{g}$ to remove migrated cells from the membrane. The tray with 96 wells of permeable inserts was removed, and the receiver plate containing the migrated cells was placed into a spectrophotometer (TECAN, Männedorf, Switzerland). Calcein-AM staining was detected at an emission length of $520 \mathrm{~nm}$. After subtraction of the blank values, the number of migrated cells was normalized to that of cells stimulated with FBS.

\subsection{Determination of Chemotactic Behaviour by Cell Tracking}

The $\mu$-slide chemotaxis assay (Ibidi, Martinsried, Germany) allows the establishment of a stable gradient and the observation of cells within this gradient via time-lapse imaging. Two reservoirs, filled either with a chemoattractant or with medium, are connected by a gap. The gap was coated with $1 \mu \mathrm{g} / \mathrm{mL}$ fibronectin (Sigma, Steinheim, Germany) one day before seeding of the cells. The gap was filled with $6 \mu \mathrm{L}$ of cell suspension with a concentration of $3 \times 10^{6}$ cells $/ \mathrm{mL}$ ( $=18,000$ cells). The NCCs were allowed to attach for $3 \mathrm{~h}$ at $37{ }^{\circ} \mathrm{C}$ and $5 \% \mathrm{CO}_{2}$. Afterwards, the reservoirs were filled with pure medium only on one side and medium containing chemoattractant on the other side. Directly afterwards, the $\mu$-slide chemotaxis slide was mounted on the stage of an Axio Observer Z1 microscope (Zeiss, Oberkochen, Germany) equipped with an Axiocam MRm camera and an incubation chamber $\left(37^{\circ} \mathrm{C}, 5 \% \mathrm{CO}_{2}\right)$. Phase contrast images were taken every $10 \mathrm{~min}$ for $24 \mathrm{~h}$ using a $5 \times$ objective. Images were exported as JPEG files, and cell tracking was performed using the 'Manual Tracking' plugin from ImageJ [66]. For each biological replicate, 20 cells were tracked per condition. The resulting cell coordinates were transferred to the 'Chemotaxis and Migration Tool V2.0' (Ibidi, Martinsried, Germany) to determine cell translocation, accumulated distance and cell speed and to generate "rose plots" of the tracked cells.

\subsection{Co-Culture and Conditioned Medium Preparation}

HepG2 hepatoma cells (ATCC, HB-8065), MDA-MB-231 breast carcinoma cells (ATCC, HTB-26), HeLa cervical cancer cells (ATCC, CCL-2), HEK-239 human embryonic kidney cells (ATCC, CRL-1573) and SH-SY5Y neuroblastoma cells (ATCC, CRL-2266) were cultured in DMEM + GlutMax ${ }^{\mathrm{TM}}$ (Gibco/Fisher Scientific, Hampton, NH, USA) supplemented with $10 \%$ fetal bovine serum (FBS) (PAA Laboratories, Pasching, Austria) and 1\% pen/strep (Gibco/Fisher Scientific, Hampton, NH, USA) at $37^{\circ} \mathrm{C}$ and $5 \% \mathrm{CO}_{2}$. Cells were passaged every other day. 
For conditioned medium (CM) preparation, the cells were seeded in DMEM + GlutMax ${ }^{\mathrm{TM}}$ (Gibco/Fisher Scientific, Hampton, NH, USA) supplemented with 10\% FBS (PAA Laboratories, Pasching, Austria) and 1\% pen/strep (Gibco/Fisher Scientific, Hampton, NH, USA) and grown until they reached confluency. The medium was aspirated, the cells were washed once with phosphate-buffered saline (PBS) and then fresh DMEM + GlutMax ${ }^{\mathrm{TM}}$ without FBS, and pen/strep was added. Cells were incubated for $24 \mathrm{~h}$. To remove any residues of FBS, the medium was again aspirated, the cells were washed once with PBS, and then fresh DMEM + GlutMax ${ }^{\mathrm{TM}}$ was added. After incubation for another $24 \mathrm{~h}$, the medium supernatant was harvested and centrifuged at $314 \times g$ for $4 \mathrm{~min}$ to remove cell debris. This conditioned medium (CM) was either used in the NC-MT assay or further processed by acetone precipitation (and the pellet stored at $-20^{\circ} \mathrm{C}$ ).

For co-culture experiments, cells were seeded at a concentration of 150,000 cells $/ \mathrm{cm}^{2}$ in 24-well plates in DMEM + GlutMax ${ }^{\mathrm{TM}}$ supplemented with $10 \%$ foetal bovine serum (FBS) (PAA Laboratories, Pasching, Austria) and 1\% pen/strep (Gibco/Fisher Scientific, Hampton, NH, USA). Cells were incubated for $24 \mathrm{~h}$. Afterwards, cells were washed once with phosphate-buffered saline (PBS) and then fresh DMEM + GlutMax $^{\mathrm{TM}}$ (Gibco/Fisher Scientific, Hampton, NH, USA) was added. The steps were analogue to the conditioned medium preparation. After $48 \mathrm{~h}$ of starvation, the inserts with seeded NCCs were placed into the wells of the 24 well plate containing starved cells.

\subsection{Human Serum and Platelet Lysate Preparation}

Approach 1 (human serum): Whole Blood was obtained from healthy adult volunteers and collected into Monovettes (7.5 mL, K3 EDTA, Sarstedt, Nümbrecht, Germany). Procedures were approved by the institutional review board (IRB) of the University of Konstanz. Before blood collection, the monovettes were washed twice with MilliQ water to remove EDTA and enable clotting. For serum preparation, whole blood was allowed to clot by leaving it undisturbed at RT for $30 \mathrm{~min}$. The clot was removed by centrifugation at $1500 \times g$ for $10 \mathrm{~min}$ at $4^{\circ} \mathrm{C}$. Supernatants were transferred immediately into fresh tubes, aliquoted and stored at $-80^{\circ} \mathrm{C}$.

Approach 2 (huPL preparation): For platelet lysate preparation, whole blood was centrifuged at $150 \times g$ for $20 \mathrm{~min}$ at RT to collect platelet-rich plasma. Only the upper half of the platelet-rich plasma was transferred into a new plastic tube and buffer $\mathrm{A}$ (10 mM sodium citrate, $150 \mathrm{mM} \mathrm{NaCl}, 1 \mathrm{mM}$ EDTA, $1 \%$ dextrose, $\mathrm{pH} 7.4$ ) containing $1 \mu \mathrm{M}$ prostaglandin (PGI2, Iloprost, Sigma, Steinheim, Germany) was added at 1:1 ratio. The mixture was centrifuged at $350 \times g$ for $15 \mathrm{~min}$ at RT. The platelet pellet was washed once in buffer B (140 mM NaCl, 6 mM KCl, 2 mM Mg $2 \mathrm{SO}_{4}, 2$ mM NaHPO, 6 mM HEPES, pH 7.4) to remove plasma residues. The pellet was resuspended in an appropriate volume of buffer $\mathrm{B}$, and the platelets were lysed by three freeze-thaw cycles at $-20^{\circ} \mathrm{C}$ and $37^{\circ} \mathrm{C}$. Finally, the platelet lysate was centrifuged at $2000 \times g$ for $15 \mathrm{~min}$ at RT to remove platelet debris. The supernatant was aliquoted and stored at $-20^{\circ} \mathrm{C}$.

Approach 3: Commercial huPLs (CRUX RUFA research (Trinova Biochem, Gießen, Germany), ELAREM ${ }^{\mathrm{TM}}$ PRIME (PL BioScience, Aachen, Germany), Stemulate ${ }^{\mathrm{TM}}$ (COOK Regentec, Indianapolis, IN, USA)) were obtained, aliquoted and stored at $-20{ }^{\circ} \mathrm{C}$. To prevent coagulation of the cell culture medium, heparin (PL-HEP-0005) was added at a final concentration of $2 \mathrm{U} / \mathrm{mL}$. No heparin was required when using Stemulate ${ }^{\mathrm{TM}}$ (COOK Regentec, Indianapolis, IN, USA).

\subsection{Acetone Precipitation}

FBS, huPL or HepG2 CM were mixed with 30\% precooled acetone (VWR Chemicals, Darmstadt, Germany) and incubated overnight at $-20{ }^{\circ} \mathrm{C}$. Samples were then centrifuged at $7000 \times g$ for $30 \mathrm{~min}$. The supernatant was transferred into a new $250 \mathrm{~mL}$ centrifuge tube (Corning, Glendale, AZ, USA), and the pellet was discarded. Then, 10\% precooled acetone (VWR Chemicals, Darmstadt, Germany) was added and again incubated overnight at $-20^{\circ} \mathrm{C}$. The sample was centrifuged at $7000 \times g$ for $30 \mathrm{~min}$. This time the supernatant was 
discarded, and the remaining pellet dried at room temperature until all acetone remains were evaporated. The pellet was stored at $-20^{\circ} \mathrm{C}$ for further usage.

\subsection{Protein Purification}

Fast protein liquid chromatography (FPLC) was used to purify complex protein mixtures. The procedure takes advantage of the fact that different proteins have different affinities to the resin of the purification columns. FPLC was performed using an ÄKTAprime plus (GE Healthcare, München, Germany) system equipped with a UV detection system. Protein separation was carried out with different ion exchange columns: a cation exchange column (HiScreen Capto SP ImpRes, GE Healthcare, München, Germany), an anion exchange column (HiTrap Q HP $1 \mathrm{~mL}$, GE Healthcare) and another anion exchange column (HiTrap Q FF $5 \mathrm{~mL}$, GE Healthcare, München, Germany). The start buffer contained $10 \mathrm{mM}$ Tris- $\mathrm{HCl}$ ( $\mathrm{pH} 7.4$ ), and the elution buffers contained additionally $2 \mathrm{M} \mathrm{MgCl}_{2}$ for the cation exchange column or $2 \mathrm{M} \mathrm{NaCl}$ for the anion exchange columns. All buffers were sterile-filtered before use. The chromatographic separation was performed using a linear gradient of the elution buffer, starting from 0 up to $50 \%$, followed by a step up to $100 \%$ (Figure S5). The protein sample was sterile-filtered before loading it to the column. FPLC separation was performed at room temperature (RT), and fractions of $1 \mathrm{~mL}$ were collected with an automated fraction collector. Within the stepwise purification process, the collected fractions were tested for bioactivity in the NC-MT assay. For this, fractions were diluted 1:4 with medium and the migration-increasing activity was tested. For further purification steps, the active fractions were combined and desalted with a desalting column (HiPrep 26/10 Desalting, GE Healthcare, München, Germany) using MilliQ water as elution buffer. Afterwards, the desalted sample was loaded on the second ion exchange column for further protein separation. The individual fractions were tested in the NC-MT assay for their migration-increasing activity.

\subsection{Protein Separation and Detection}

For polyacrylamide gel electrophoresis (PAGE), samples were lysed in $1 \times$ Laemmli buffer and boiled for $5 \mathrm{~min}$ at $95^{\circ} \mathrm{C}$. Thirty-five micrograms of total protein were loaded on $10 \%$ PAA gels. Protein separation was performed in running buffer $(250 \mathrm{mM}$ tris base, $1.9 \mathrm{M}$ glycine, $34.7 \mathrm{mM}$ SDS, $\mathrm{pH} 8.3$ ) with constant $80 \mathrm{~V}$ and maximum $300 \mathrm{~mA}$ for $2 \mathrm{~h}$. The gel was then stained with coomassie blue dye (InstantBlue, VWR Chemicals, Darmstadt, Germany) for $20 \mathrm{~min}$ or overnight and afterwards washed twice with desalted water. Silver stainings were performed according to the instruction manual of the Pierce ${ }^{\mathrm{TM}}$ Silver Stain for Mass Spectrometry kit (Pierce/Thermo Fisher Scientific, Rockford, IL, USA, catalog no. 24600).

For Western blotting, samples were lysed in $1 \times$ Laemmli buffer and boiled for $5 \mathrm{~min}$ at $95{ }^{\circ} \mathrm{C}$. Thirty-five micrograms of total protein were loaded on $10 \%$ PAA gels. Protein separation was performed in running buffer $(250 \mathrm{mM}$ tris base, $1.9 \mathrm{M}$ glycine, $34.7 \mathrm{mM}$ SDS, $\mathrm{pH}$ 8.3) with constant $80 \mathrm{~V}$ and maximum $300 \mathrm{~mA}$. Afterwards, proteins were transferred at $20 \mathrm{~V}$ for $5 \mathrm{~min}$ onto nitrocellulose membranes (Amersham, Buckinghamshire, UK) using the Invitrogen iBlot 2 system. Membranes were blocked with $5 \%$ milk powder $(w / v)$ in $0.1 \%$ TBS-Tween $(v / v)$ for at least $1 \mathrm{~h}$. Fibronectin antibody ab45688 (Abcam, Cambridge, UK), alpha 1 fetoprotein (AFP) antibody ab133617 (Abcam, Cambridge, UK) and glyceraldehyde 3-phosphate dehydrogenase (GAPDH) antibody ZG003 (Thermo Fisher Scientific, Waltham, MA, US) were incubated at $4{ }^{\circ} \mathrm{C}$ overnight. After washing steps with $0.1 \%$ TBS-Tween $(v / v)$, the secondary antibody (peroxidase-conjugated AffiniPure goat anti-mouse IgG (Jackson Immunoresearch, Cambridge, UK) or horseradish peroxidase-conjugated donkey anti-rabbit IgG (GE Healthcare, München, Germany) was incubated for $1 \mathrm{~h}$ at RT. For visualization, ECL Western blotting substrate (Pierce/Thermo Fisher Scientific, Rockford, IL, USA) was used.

For protein quantification, the Quick Start ${ }^{\mathrm{TM}}$ Bradford protein assay kit (Bio Rad, München, Germany) was used, and the assay was performed according to the instruction 
manual of the manufacturer. BSA was used as protein standard with concentrations from $2 \mathrm{mg} / \mathrm{mL}$ down to $1.25 \mu \mathrm{g} / \mathrm{mL}$. The assay was performed in a 96-well plate, and BSA standard dilutions and sample dilutions were added in triplicates to the wells, respectively. After incubation for $5 \mathrm{~min}$ at room temperature, the absorbance was measured at $595 \mathrm{~nm}$ with a spectrophotometer (TECAN, Männedorf, Switzerland).

\subsection{Mass Spectrometry (MS) for Protein Identification}

The active fractions from the NC-MT assay were separated in a 10\% SDS gel and stained with coomassie blue (InstantBlue, VWR Chemicals, Darmstadt, Germany) or a silver stain kit for mass spectrometry (Pierce/Thermo Fisher Scientific, Rockford, Illinois, USA, catalog no. 24600). The protein bands of interest were cut out, and all further steps were performed at the Proteomics Center of the University of Konstanz.

For sample preparation, all samples were reduced with DTT $\left(30 \mathrm{~min}, 56^{\circ} \mathrm{C}\right)$ and alkylated with chloroacetamide (60 min, RT). Digestions were performed using Trypsin $\left(16 \mathrm{~h}, 30^{\circ} \mathrm{C}\right)$.

All digests were analyzed on a QExactive HF mass spectrometer (Thermo Fisher Scientific, Bremen, Germany) interfaced with an Easy-nLC 1200 nanoflow liquid chromatography system (Thermo Fisher Scientific, Bremen, Germany). The peptide digests were reconstituted in $0.1 \%$ formic acid and loaded onto the analytical column $(75 \mu \mathrm{m} \times 15 \mathrm{~cm})$. Peptides were resolved at a flow rate of $300 \mathrm{~nL} / \mathrm{min}$ using a linear gradient of $6-45 \%$ solvent $\mathrm{B}$ ( $0.1 \%$ formic acid in $80 \%$ acetonitrile) over $45 \mathrm{~min}$. Data-dependent acquisition with full scans in a $350-1500 \mathrm{~m} / \mathrm{z}$ range was carried out at a mass resolution of 120,000. The 15 most intense precursor ions were selected for fragmentation. Peptides with charge states $2-7$ were selected, and dynamic exclusion was set to $30 \mathrm{sec}$. Precursor ions were fragmented using higher-energy collision dissociation (HCD) set to $28 \%$.

For data evaluation, the raw data were searched against a suitable database using Proteome Discoverer 1.4 (Thermo Scientific).

\subsection{Heat Inactivation and Pepsin Digestion}

FBS, huPL and HepG2 CM samples were heat treated under different conditions. Therefore, the samples were incubated in heating blocks with temperatures of $60^{\circ} \mathrm{C}$ and $70{ }^{\circ} \mathrm{C}$ for $30 \mathrm{~min}$ and in heat blocks with temperatures of $80^{\circ} \mathrm{C}$ and $90^{\circ} \mathrm{C}$ for $15 \mathrm{~min}$.

For pepsin digestion, FBS, huPL and HepG2 CM samples were mixed with pepsin solution, resulting in a final concentration of $0.5 \%$ pepsin $(w / v)$. The $\mathrm{pH}$ was adjusted to $\mathrm{pH}=2$ with a $1 \mathrm{M} \mathrm{HCl}$ solution and controlled with $\mathrm{pH}$ strips. The samples were incubated at $37^{\circ} \mathrm{C}$ in a water bath. After $1 \mathrm{~h}$ of incubation, the $\mathrm{pH}$ of the sample was adjusted to $\mathrm{pH}=7$ by adding $1 \mathrm{M} \mathrm{NaOH}$ solution to stop the pepsin reaction. The control sample was run through the same acidification-incubation procedure but without pepsin. Control samples were prepared for each condition to exclude the influence of $\mathrm{pH}$ change on the sample activity.

\subsection{Stability Control Tests}

Collected fractions after ion exchange chromatography were tested directly in the NC-MT assay for their migration-increasing activity. The remaining fractions were stored for $24 \mathrm{~h}$ under different conditions: samples were left either at $4{ }^{\circ} \mathrm{C}$ or frozen at $-80^{\circ} \mathrm{C}$, samples were mixed with $1 \times$ protease inhibitor cocktail (cOmplete tablets, Roche, Basel, Switzerland) and stored at $4{ }^{\circ} \mathrm{C}$, samples were shock frozen in liquid nitrogen and stored at $-80{ }^{\circ} \mathrm{C}$, samples were mixed with $0.5 \%$ BSA and stored at $4{ }^{\circ} \mathrm{C}$ and $-80{ }^{\circ} \mathrm{C}$, and samples were mixed with $20 \%$ glycerol and stored at $-80^{\circ} \mathrm{C}$. After $24 \mathrm{~h}$ of incubation, the samples were retested in the NC-MT assay for their migration-increasing activity.

\subsection{Fractionation of Proteins According to Their Molecular Weight}

Centrifugal filter devices (Amicon ${ }^{\circledR}$ - Ultra-0.5, Merck Millipore, Burlington, MA, USA) in five different "cut-off" sizes $(3 \mathrm{~K}, 10 \mathrm{~K}, 30 \mathrm{~K}, 50 \mathrm{~K}, 100 \mathrm{~K} ; \mathrm{K}=1000 \mathrm{Da})$ were 
filled with $500 \mu \mathrm{L}$ sample and centrifuged for $15 \mathrm{~min}$ at $14,000 \times g$ at RT. The collection tube (filtrate) contained proteins smaller than the molecular cut-off. Proteins larger than the cut-off remained in the filter device after centrifugation (supernatant). To recover the sample in the filter device, the device was placed upside down in an empty tube and centrifuged for two minutes at $1000 \times g$ at RT.

\subsection{Data Handling and Statistics}

If not stated otherwise, values are expressed as means of at least three different experiments (i.e., using three different cell preparations), with at least three technical replicates per cell preparation. Statistical differences were tested by ANOVA with post hoc tests as appropriate, using GraphPad Prism 7.0 (Graphpad Software, La Jolla, USA, www.graphpad.com).

\section{Conclusions and Outlook}

Altogether, we have shown here that it is possible to establish an in vitro assay for directed migration of human neural crest cells (chemotaxis), a pivotal process in fetal development. Human material can be exclusively used for the assay, and it goes beyond the assessment of non-directed movement capacity (chemokinesis). Thus, it can be used to study processes and factors (pathological, toxicological or pharmacological) that specifically affect the sensing of a chemoattractive gradient and accordingly the directed movement of NCCs. We also demonstrated that the assay allows a highly quantitative readout, as it was successfully used here for determining the bioactivity spectrum of chromatographic fractions or of CTA preparations after various treatments (heat, proteases, etc.). This is a key feature that is important for the development of new approach methods (NAMs) that can be used for testing potential developmental toxicants (in particular developmental neurotoxicants). In the past, tremendous research has been invested in animal models of neural crest migration, and the search for human-relevant chemotactic factors has been neglected. For this purpose, ground work, as described here, is essential for providing a basis of a new generation of tests based only on human cells and human-relevant material and processes (here chemoattractant factors, cell culture coating, cell culture medium). Even though we have not yet succeeded in identifying a protein that can be produced recombinantly and then be used for such assays, here, we have provided protocols, which show how suitable protein fractions can be produced to establish a NAM.

We described here three sources of CTA: HepG2 supernatant, huPL and serum. For the latter source, most work focused on FBS, but we showed that human serum is also bioactive. Indeed, we do not have perfect proof that the chemotaxis-promoting factor in huPL is a platelet protein. Commercially available huPL always contained serum proteins. As an alternative approach, we produced purified platelets ourselves. These contained distinctly less plasma proteins than commercial huPL, but we cannot completely exclude contaminations.

Possibly, there is not only one protein with CTA, and such factors may work independently, or they may work synergistically. We believe that there is strong evidence for at least one factor present in serum. First, because we find CTA in cell-free serum; second, because HepG2 cells, which are known to produce serum proteins [67,68], produce such a factor. Whether the factor found in serum and the one in HepG2 supernatants (or huPL) is the same protein cannot be decided on the basis of the available data.

For better defining the protein factor, additional efforts are necessary. The combination of better chromatographic approaches together with extensive mass spectrometric characterization of all fractions may provide a step forward. However, this strategy can only be fully developed, if it is possible to stabilize and store highly bioactive fractions. At present, the loss of bioactivity of the most active fractions within $24 \mathrm{~h}$ makes purification strategies extremely challenging. Additionally, increasing the amount of starting material is limited by the binding capacity of the chromatographic columns. To circumvent these limi- 
tations, the removal of unwanted proteins from the starting material and simultaneously the concentration of the remaining proteins (e.g., by a precipitation step) is necessary.

Another issue is the potentially high bioactivity of a chemotactic factor together with its extreme dilution by other proteins. If the factor has hormone/cytokine-like properties, it is likely to have low $\mathrm{nM}$ or even $\mathrm{pM}$ affinities and may therefore only be present in $\mathrm{pM}$ concentrations. Such a protein might be easily masked by highly abundant serum proteins, e.g., upon gel separation. Such issues are well-known in biology, and some of the most obvious and important bioactive molecules could never be purified by traditional methods. This applies, e.g., to the erythropoietin receptor, the corticotrophic hormone receptor or the tumor necrosis factor receptor, which were all eventually identified by functional expression cloning [69-71]. Such strategies may be used in the future for identification of chemotaxis factors, considering that the bioassay works at relatively high throughput.

The above purification strategies are of mid-term and long-term interest, as they inform on the underlying human physiology. They may also offer some advantages for assay development and application. However, a purified factor is by no means necessary to go ahead. Biology has a long and successful tradition of using complex materials, often not fully defined in their composition, for quantitative assays. We have shown here procedures to purify the CTA several thousand-fold, which is already an intermediate step towards a more defined material. Most importantly, we demonstrated how FBS could be exchanged for fully human material, and on this basis, a complete humanized NAM can be established.

Supplementary Materials: The following are available online at https:/ /www.mdpi.com/article/10 .3390/ijms221810079/s1.

Author Contributions: Conceptualization, X.D., C.K. and M.L.; methodology, X.D. and S.S.; software, C.K.; validation, X.D. and M.W.; formal analysis, X.D.; investigation, X.D., M.W. and S.S.; resources, X.D., S.S., C.K. and M.W.; data curation, X.D.; writing-original draft preparation, X.D. and M.L.; writing - review and editing, all authors; visualization, X.D.; supervision, M.L.; project administration, M.L.; funding acquisition, M.L. All authors have read and agreed to the published version of the manuscript.

Funding: This work was supported by CEFIC, the BMBF, EFSA and the DK-EPA (MST-667-00205). It has received funding from the Land-BW (NAM-ACCEPT) and the European Union's Horizon 2020 research and innovation program under grant agreements No. 681002 (EU-ToxRisk), No. 964537 (RISK-HUNT3R), No. 964518 (ToxFree) and No. 825759 (ENDpoiNTs).

Institutional Review Board Statement: Ethical review and approval were waived for this study, as the involved subject is an author of this study.

Informed Consent Statement: Informed consent was obtained from all subjects involved in the study.

Data Availability Statement: Data is contained within the article or supplementary material.

Acknowledgments: The Proteomics Center of the University of Konstanz and the Konstanz Research School Chemical Biology (KoRS-CB) are acknowledged for providing excellent support.

Conflicts of Interest: The authors declare no conflict of interest.

$\begin{array}{ll}\text { Abbreviations } \\ \text { cMINC } & \text { circular MINC } \\ \text { DMSO } & \text { dimethyl sulfoxide } \\ \text { DNT } & \text { developmental neurotoxicity } \\ \text { ECM } & \text { extracellular matrix } \\ \text { EGF } & \text { epidermal growth factor } \\ \text { FBS } & \text { fetal bovine serum } \\ \text { FGF } & \text { fibroblast growth factor } \\ \text { FPLC } & \text { fast protein liquid chromatography } \\ \text { HTS } & \text { high-throughput screening } \\ \text { huPL } & \text { human platelet lysate }\end{array}$




$\begin{array}{ll}\text { iPSC } & \text { induced pluripotent stem cell } \\ \text { MINC } & \text { migration inhibition of neural crest cell } \\ \text { MW } & \text { molecular weight } \\ \text { NAM } & \text { new approach method } \\ \text { NCC } & \text { neural crest cell } \\ \text { NC-MT } & \text { neural crest membrane translocation } \\ \text { NGRA } & \text { next generation risk assessment } \\ \text { PBS } & \text { phosphate buffered saline } \\ \text { PCB } & \text { polychlorinated biphenyl } \\ \text { PDGF } & \text { platelet derived growth factor } \\ \text { RA } & \text { retinoic acid } \\ \text { SDF-1 } & \text { stromal cell derived factor 1 } \\ \text { VEGF } & \text { vascular endothelium growth factor } \\ \text { VPA } & \text { valproic acid }\end{array}$

\section{References}

1. Vega-Lopez, G.A.; Cerrizuela, S.; Tribulo, C.; Aybar, M.J. Neurocristopathies: New insights 150 years after the neural crest discovery. Dev. Biol. 2018, 444, S110-S143. [CrossRef] [PubMed]

2. Serrano, F.; Bernard, W.G.; Granata, A.; Iyer, D.; Steventon, B.; Kim, M.; Vallier, L.; Gambardella, L.; Sinha, S. A novel human pluripotent stem cell-derived neural crest model of treacher collins syndrome shows defects in cell death and migration. Stem Cells Dev. 2019, 28, 81-100. [CrossRef]

3. Zhang, P.; Wang, G.; Lin, Z.; Wu, Y.; Zhang, J.; Liu, M.; Lee, K.K.H.; Chuai, M.; Yang, X. Alcohol exposure induces chick craniofacial bone defects by negatively affecting cranial neural crest development. Toxicol. Lett. 2017, 281, 53-64. [CrossRef] [PubMed]

4. Menegola, E.; Broccia, M.L.; Di Renzo, F.; Massa, V.; Giavini, E. Craniofacial and axial skeletal defects induced by the fungicide triadimefon in the mouse. Birth Defects Res. Part B Dev. Reprod. Toxicol. 2005, 74, 185-195. [CrossRef] [PubMed]

5. Williams, A.L.; Bohnsack, B.L. What's retinoic acid got to do with it? Retinoic acid regulation of the neural crest in craniofacial and ocular development. Genesis 2019, 57, e23308. [CrossRef] [PubMed]

6. Le Douarin, N.M. The avian embryo as a model to study the development of the neural crest: A long and still ongoing story. Mech. Dev. 2004, 121, 1089-1102. [CrossRef]

7. Prasad, M.S.; Charney, R.M.; Garcia-Castro, M.I. Specification and formation of the neural crest: Perspectives on lineage segregation. Genesis 2019, 57, e23276. [CrossRef]

8. Sieber-Blum, M. Cardiac neural crest stem cells. Anat. Rec. Part A Discov. Mol. Cell. Evol. Biol. 2004, 276, 34-42. [CrossRef]

9. Giovannone, D.; Ortega, B.; Reyes, M.; El-Ghali, N.; Rabadi, M.; Sao, S.; de Bellard, M.E. Chicken trunk neural crest migration visualized with hnk1. Acta Histochem. 2015, 117, 255-266. [CrossRef]

10. Huang, M.; Miller, M.L.; McHenry, L.K.; Zheng, T.; Zhen, Q.; Ilkhanizadeh, S.; Conklin, B.R.; Bronner, M.E.; Weiss, W.A. Generating trunk neural crest from human pluripotent stem cells. Sci. Rep. 2016, 6, 19727. [CrossRef]

11. Conway, J.R.W.; Jacquemet, G. Cell matrix adhesion in cell migration. Essays Biochem. 2019, 63, 535-551.

12. Ridley, A.J.; Schwartz, M.A.; Burridge, K.; Firtel, R.A.; Ginsberg, M.H.; Borisy, G.; Parsons, J.T.; Horwitz, A.R. Cell migration: Integrating signals from front to back. Science 2003, 302, 1704-1709. [CrossRef]

13. Shellard, A.; Mayor, R. Chemotaxis during neural crest migration. Semin. Cell Dev. Biol. 2016, 55, 111-118. [CrossRef] [PubMed]

14. Kay, R.R.; Langridge, P.; Traynor, D.; Hoeller, O. Changing directions in the study of chemotaxis. Nat. Rev. Mol. Cell Biol. 2008, 9, 455-463. [CrossRef] [PubMed]

15. Wu, D. Signaling mechanisms for regulation of chemotaxis. Cell Res. 2005, 15, 52-56. [CrossRef] [PubMed]

16. Nieto, M.A.; Huang, R.Y.; Jackson, R.A.; Thiery, J.P. Emt: 2016. Cell 2016, 166, 21-45. [CrossRef]

17. Capuana, L.; Boström, A.; Etienne-Manneville, S. Multicellular scale front-to-rear polarity in collective migration. Curr. Opin. Cell Biol. 2020, 62, 114-122. [CrossRef]

18. Merchant, B.; Feng, J.J. A rho-gtpase based model explains group advantage in collective chemotaxis of neural crest cells. Phys. Biol. 2020, 17, 036002. [CrossRef]

19. Mayor, R.; Etienne-Manneville, S. The front and rear of collective cell migration. Nat. Rev. Mol. Cell Biol. 2016, 17, 97-109. [CrossRef]

20. McLennan, R.; Schumacher, L.J.; Morrison, J.A.; Teddy, J.M.; Ridenour, D.A.; Box, A.C.; Semerad, C.L.; Li, H.; McDowell, W.; Kay, D.; et al. Vegf signals induce trailblazer cell identity that drives neural crest migration. Dev. Biol. 2015, 407, 12-25. [CrossRef] [PubMed]

21. McLennan, R.; Teddy, J.M.; Kasemeier-Kulesa, J.C.; Romine, M.H.; Kulesa, P.M. Vascular endothelial growth factor (vegf) regulates cranial neural crest migration in vivo. Dev. Biol. 2010, 339, 114-125. [CrossRef]

22. Eberhart, J.K.; He, X.; Swartz, M.E.; Yan, Y.L.; Song, H.; Boling, T.C.; Kunerth, A.K.; Walker, M.B.; Kimmel, C.B.; Postlethwait, J.H. Microrna mirn140 modulates pdgf signaling during palatogenesis. Nat. Genet. 2008, 40, 290-298. [CrossRef] 
23. Kubota, Y.; Ito, K. Chemotactic migration of mesencephalic neural crest cells in the mouse. Dev. Dyn. Off. Publ. Am. Assoc. Anat. 2000, 217, 170-179. [CrossRef]

24. Kasemeier-Kulesa, J.C.; McLennan, R.; Romine, M.H.; Kulesa, P.M.; Lefcort, F. Cxcr4 controls ventral migration of sympathetic precursor cells. J. Neurosci. Off. J. Soc. Neurosci. 2010, 30, 13078-13088. [CrossRef] [PubMed]

25. Bahm, I.; Barriga, E.H.; Frolov, A.; Theveneau, E.; Frankel, P.; Mayor, R. Pdgf controls contact inhibition of locomotion by regulating n-cadherin during neural crest migration. Development 2017, 144, 2456-2468. [PubMed]

26. Theveneau, E.; Marchant, L.; Kuriyama, S.; Gull, M.; Moepps, B.; Parsons, M.; Mayor, R. Collective chemotaxis requires contact-dependent cell polarity. Dev. Cell 2010, 19, 39-53. [CrossRef] [PubMed]

27. Hackland, J.O.S.; Frith, T.J.R.; Thompson, O.; Marin Navarro, A.; Garcia-Castro, M.I.; Unger, C.; Andrews, P.W. Top-down inhibition of bmp signaling enables robust induction of hpscs into neural crest in fully defined, xeno-free conditions. Stem Cell Rep. 2017, 9, 1043-1052. [CrossRef]

28. Hackland, J.O.S.; Frith, T.J.R.; Andrews, P.W. Fully defined and xeno-free induction of hpscs into neural crest using top-down inhibition of bmp signaling. Methods Mol. Biol. 2019, 1976, 49-54.

29. Tchieu, J.; Zimmer, B.; Fattahi, F.; Amin, S.; Zeltner, N.; Chen, S.; Studer, L. A modular platform for differentiation of human pscs into all major ectodermal lineages. Cell Stem Cell 2017, 21, 399-410. [CrossRef]

30. Zimmer, B.; Lee, G.; Balmer, N.V.; Meganathan, K.; Sachinidis, A.; Studer, L.; Leist, M. Evaluation of developmental toxicants and signaling pathways in a functional test based on the migration of human neural crest cells. Environ. Health Perspect. 2012, 120, 1116-1122. [CrossRef]

31. Chambers, S.M.; Mica, Y.; Lee, G.; Studer, L.; Tomishima, M.J. Dual-smad inhibition/wnt activation-based methods to induce neural crest and derivatives from human pluripotent stem cells. Methods Mol. Biol. 2016, 1307, 329-343.

32. Srinivasan, A.; Toh, Y.C. Human pluripotent stem cell-derived neural crest cells for tissue regeneration and disease modeling. Front. Mol. Neurosci. 2019, 12, 39. [CrossRef]

33. Workman, M.J.; Mahe, M.M.; Trisno, S.; Poling, H.M.; Watson, C.L.; Sundaram, N.; Chang, C.F.; Schiesser, J.; Aubert, P.; Stanley, E.G.; et al. Engineered human pluripotent-stem-cell-derived intestinal tissues with a functional enteric nervous system. Nat. Med. 2017, 23, 49-59. [CrossRef]

34. Lee, G.; Papapetrou, E.P.; Kim, H.; Chambers, S.M.; Tomishima, M.J.; Fasano, C.A.; Ganat, Y.M.; Menon, J.; Shimizu, F.; Viale, A.; et al. Modelling pathogenesis and treatment of familial dysautonomia using patient-specific ipscs. Nature 2009, 461, 402-406. [CrossRef]

35. Zeltner, N.; Fattahi, F.; Dubois, N.C.; Saurat, N.; Lafaille, F.; Shang, L.; Zimmer, B.; Tchieu, J.; Soliman, M.A.; Lee, G.; et al. Capturing the biology of disease severity in a psc-based model of familial dysautonomia. Nat. Med. 2016, 22, 1421-1427. [CrossRef]

36. Nyffeler, J.; Dolde, X.; Krebs, A.; Pinto-Gil, K.; Pastor, M.; Behl, M.; Waldmann, T.; Leist, M. Combination of multiple neural crest migration assays to identify environmental toxicants from a proof-of-concept chemical library. Arch. Toxicol. 2017, 91, 3613-3632. [CrossRef]

37. Hartung, T. Toxicology for the twenty-first century. Nature 2009, 460, 208-212. [CrossRef] [PubMed]

38. Hartung, T.; Leist, M. Food for thought... On the evolution of toxicology and the phasing out of animal testing. Altex 2008, 25, 91-102. [CrossRef] [PubMed]

39. Collins, F.S.; Gray, G.M.; Bucher, J.R. Toxicology. Transforming environmental health protection. Science 2008, 319, 906-907. [CrossRef] [PubMed]

40. Crofton, K.M.; Mundy, W.R.; Shafer, T.J. Developmental neurotoxicity testing: A path forward. Congenit. Anom. 2012, 52, 140-146. [CrossRef] [PubMed]

41. Aschner, M.; Ceccatelli, S.; Daneshian, M.; Fritsche, E.; Hasiwa, N.; Hartung, T.; Hogberg, H.T.; Leist, M.; Li, A.; Mundi, W.R.; et al. Reference compounds for alternative test methods to indicate developmental neurotoxicity (dnt) potential of chemicals: Example lists and criteria for their selection and use. Altex 2017, 34, 49-74. [CrossRef]

42. Bal-Price, A.; Hogberg, H.T.; Crofton, K.M.; Daneshian, M.; FitzGerald, R.E.; Fritsche, E.; Heinonen, T.; Hougaard Bennekou, S.; Klima, S.; Piersma, A.H.; et al. Recommendation on test readiness criteria for new approach methods in toxicology: Exemplified for developmental neurotoxicity. Altex 2018, 35, 306-352. [CrossRef]

43. Krebs, A.; van Vugt-Lussenburg, B.M.A.; Waldmann, T.; Albrecht, W.; Boei, J.; Ter Braak, B.; Brajnik, M.; Braunbeck, T.; Brecklinghaus, T.; Busquet, F.; et al. The eu-toxrisk method documentation, data processing and chemical testing pipeline for the regulatory use of new approach methods. Arch. Toxicol. 2020, 94, 2435-2461. [CrossRef] [PubMed]

44. Smirnova, L.; Hogberg, H.T.; Leist, M.; Hartung, T. Developmental neurotoxicity-challenges in the 21st century and in vitro opportunities. Altex 2014, 31, 129-156.

45. Zimmer, B.; Pallocca, G.; Dreser, N.; Foerster, S.; Waldmann, T.; Westerhout, J.; Julien, S.; Krause, K.H.; van Thriel, C.; Hengstler, J.G.; et al. Profiling of drugs and environmental chemicals for functional impairment of neural crest migration in a novel stem cell-based test battery. Arch. Toxicol. 2014, 88, 1109-1126. [CrossRef]

46. Baltazar, M.T.; Cable, S.; Carmichael, P.L.; Cubberley, R.; Cull, T.; Delagrange, M.; Dent, M.P.; Hatherell, S.; Houghton, J.; Kukic, P.; et al. A next-generation risk assessment case study for coumarin in cosmetic products. Toxicol. Sci. Off. J. Soc. Toxicol. 2020, 176, 236-252. [CrossRef] [PubMed] 
47. Vinken, M.; Benfenati, E.; Busquet, F.; Castell, J.; Clevert, D.A.; de Kok, T.; Dirven, H.; Fritsche, E.; Geris, L.; Gozalbes, R.; et al. Safer chemicals using less animals: Kick-off of the european ontox project. Toxicology 2021, 458, 152846. [CrossRef] [PubMed]

48. Moné, M.J.; Pallocca, G.; Escher, S.E.; Exner, T.; Herzler, M.; Bennekou, S.H.; Kamp, H.; Kroese, E.D.; Leist, M.; Steger-Hartmann, T.; et al. Setting the stage for next-generation risk assessment with non-animal approaches: The eu-toxrisk project experience. Arch. Toxicol. 2020, 94, 3581-3592. [CrossRef] [PubMed]

49. Lee, G.; Chambers, S.M.; Tomishima, M.J.; Studer, L. Derivation of neural crest cells from human pluripotent stem cells. Nat. Protoc. 2010, 5, 688-701. [CrossRef] [PubMed]

50. Nyffeler, J.; Karreman, C.; Leisner, H.; Kim, Y.J.; Lee, G.; Waldmann, T.; Leist, M. Design of a high-throughput human neural crest cell migration assay to indicate potential developmental toxicants. Altex 2017, 34, 75-94. [CrossRef]

51. Dreser, N.; Zimmer, B.; Dietz, C.; Sugis, E.; Pallocca, G.; Nyffeler, J.; Meisig, J.; Bluthgen, N.; Berthold, M.R.; Waldmann, T.; et al. Grouping of histone deacetylase inhibitors and other toxicants disturbing neural crest migration by transcriptional profiling. Neurotoxicology 2015, 50, 56-70. [CrossRef]

52. Nyffeler, J.; Chovancova, P.; Dolde, X.; Holzer, A.K.; Purvanov, V.; Kindinger, I.; Kerins, A.; Higton, D.; Silvester, S.; van Vugt-Lussenburg, B.M.A.; et al. A structure-activity relationship linking non-planar pcbs to functional deficits of neural crest cells: New roles for connexins. Arch. Toxicol. 2018, 92, 1225-1247. [CrossRef]

53. Boyden, S. The chemotactic effect of mixtures of antibody and antigen on polymorphonuclear leucocytes. J. Exp. Med. 1962, 115, 453-466. [CrossRef] [PubMed]

54. Mastyugin, V.; McWhinnie, E.; Labow, M.; Buxton, F. A quantitative high-throughput endothelial cell migration assay. J. Biomol. Screen. 2004, 9, 712-718. [CrossRef] [PubMed]

55. Pallocca, G.; Nyffeler, J.; Dolde, X.; Grinberg, M.; Gstraunthaler, G.; Waldmann, T.; Rahnenfuhrer, J.; Sachinidis, A.; Leist, M. Impairment of human neural crest cell migration by prolonged exposure to interferon-beta. Arch. Toxicol. 2017, 91, 3385-3402. [CrossRef] [PubMed]

56. Klose, J.; Pahl, M.; Bartmann, K.; Bendt, F.; Blum, J.; Dolde, X.; Förster, N.; Holzer, A.K.; Hübenthal, U.; Keßel, H.E.; et al. Neurodevelopmental toxicity assessment of flame retardants using a human dnt in vitro testing battery. Cell Biol. Toxicol. 2021, $1-27$.

57. Anderson, N.L.; Anderson, N.G. The human plasma proteome: History, character, and diagnostic prospects. Mol. Cell. Proteom. MCP 2002, 1, 845-867. [CrossRef]

58. Morinaga, T.; Sakai, M.; Wegmann, T.G.; Tamaoki, T. Primary structures of human alpha-fetoprotein and its mrna. Proc. Natl. Acad. Sci. USA 1983, 80, 4604-4608. [CrossRef]

59. Bennett, J.A.; Zhu, S.; Pagano-Mirarchi, A.; Kellom, T.A.; Jacobson, H.I. Alpha-fetoprotein derived from a human hepatoma prevents growth of estrogen-dependent human breast cancer xenografts. Clin. Cancer Res. Off. J. Am. Assoc. Cancer Res. 1998, 4, 2877-2884.

60. Chou, M.L.; Burnouf, T. Current methods to manufacture human platelet lysates for cell therapy and tissue engineering: Possible trends in product safety and standardization. ISBT Sci. Ser. 2017, 12, 168-175. [CrossRef]

61. Horn, P.; Bokermann, G.; Cholewa, D.; Bork, S.; Walenda, T.; Koch, C.; Drescher, W.; Hutschenreuther, G.; Zenke, M.; Ho, A.D.; et al. Impact of individual platelet lysates on isolation and growth of human mesenchymal stromal cells. Cytotherapy 2010, 12, 888-898. [CrossRef] [PubMed]

62. Baud, A.; Wessely, F.; Mazzacuva, F.; McCormick, J.; Camuzeaux, S.; Heywood, W.E.; Little, D.; Vowles, J.; Tuefferd, M.; Mosaku, O.; et al. Multiplex high-throughput targeted proteomic assay to identify induced pluripotent stem cells. Anal. Chem. 2017, 89, 2440-2448. [CrossRef]

63. Mica, Y.; Lee, G.; Chambers, S.M.; Tomishima, M.J.; Studer, L. Modeling neural crest induction, melanocyte specification, and disease-related pigmentation defects in hescs and patient-specific ipscs. Cell Rep. 2013, 3, 1140-1152. [CrossRef] [PubMed]

64. Stiegler, N.V.; Krug, A.K.; Matt, F.; Leist, M. Assessment of chemical-induced impairment of human neurite outgrowth by multiparametric live cell imaging in high-density cultures. Toxicol. Sci. Off. J. Soc. Toxicol. 2011, 121, 73-87. [CrossRef] [PubMed]

65. Krug, A.K.; Balmer, N.V.; Matt, F.; Schonenberger, F.; Merhof, D.; Leist, M. Evaluation of a human neurite growth assay as specific screen for developmental neurotoxicants. Arch. Toxicol. 2013, 87, 2215-2231. [CrossRef] [PubMed]

66. Schneider, C.A.; Rasband, W.S.; Eliceiri, K.W. Nih image to imagej: 25 years of image analysis. Nat. Methods 2012, 9, 671-675. [CrossRef]

67. Franko, A.; Hartwig, S.; Kotzka, J.; Ruoss, M.; Nussler, A.K.; Konigsrainer, A.; Haring, H.U.; Lehr, S.; Peter, A. Identification of the secreted proteins originated from primary human hepatocytes and hepg2 cells. Nutrients 2019, 11, 1795. [CrossRef]

68. Trefts, E.; Gannon, M.; Wasserman, D.H. The liver. Curr. Biol. CB 2017, 27, R1147-R1151. [CrossRef] [PubMed]

69. Beutler, B.; Mahoney, J.; Le Trang, N.; Pekala, P.; Cerami, A. Purification of cachectin, a lipoprotein lipase-suppressing hormone secreted by endotoxin-induced raw 264.7 cells. J. Exp. Med. 1985, 161, 984-995. [CrossRef]

70. Chen, R.; Lewis, K.A.; Perrin, M.H.; Vale, W.W. Expression cloning of a human corticotropin-releasing-factor receptor. Proc. Natl. Acad. Sci. USA 1993, 90, 8967-8971. [CrossRef]

71. D'Andrea, A.D.; Lodish, H.F.; Wong, G.G. Expression cloning of the murine erythropoietin receptor. Cell 1989, 57, $277-285$. [CrossRef] 